\title{
The role of media reporting in food safety governance in China: a dairy case study
}

\author{
by Zhu, Z., Huang, I.Y. and Manning, L.
}

Copyright, Publisher and Additional Information: This is the author accepted manuscript. The final published version (version of record) is available online via Elsevier.

This version is made available under the CC-BY-ND-NC licence:

https://creativecommons.org/licenses/by-nc-nd/4.0/legalcode

Please refer to any applicable terms of use of the publisher

DOI: https://doi.org/10.1016/j.foodcont.2018.08.027 
The role of media reporting in food safety governance in China: a dairy case study

\title{
Xinyi Zhu, Iona Yuelu Huang and Louise Manning*
}

\author{
Harper Adams University, Newport, Shropshire, TF10 8NB
}

*corresponding author

\begin{abstract}
Using dairy products as the case study of interest, the aim of the research is to explore the role of the media in food safety governance in China. Thematic content analysis is used to evaluate government and media reports $(n=233)$ on dairy related food safety incidents in China between 2004 and 2017 with differences identified between government and media reporting. The data is extracted from an online database (Zhichuchuangwai). The results show that the government performs better on exposing incidents earlier within the 14-year period but the news media plays a complementary role in food safety governance exposing a wider coverage of incidents. This study extends the current literature on the role of the news media in food safety governance in China by focusing on a single food sector (dairy), but on a national scale.
\end{abstract}

Keywords food safety, disclosure, media, governance,

\section{Highlights}

- Food safety governance in China shows emergent hybrid characteristics.

- Media communication has an important and complementary role in food safety governance.

- Media only reported dairy product incidents tended to focus on those identified in the home. 


\section{Introduction}

Recurrent food safety incidents in China have exerted a profound negative impact on consumer confidence and the wider international reputation of the Chinese food industry (Jia \& Jukes, 2013; Peng, Li, Xia, Qi \& Li, 2015; Liu \& Ma, 2016). Since the 1990s, China has experienced both rapid industrialisation and urbanisation, causing great change in the food supply chain (Zhang \& Xue, 2016). China's food safety systems have a unique set of challenges to address including the countries geography and size, historical weak institutional governance and poor design of regulatory instruments and resource constraints, especially local regulatory resources (Holtkamp, Liu \& McGuire, 2014) although steps have been taken to address the latter constraint in recent years.

Milk is a commodity of interest in China when considering food safety, fraudulent behaviour (such as adulteration) and overall integrity in the food supply chain. What constitutes food safety is debated especially as wider definitions arise such as food defense, food fraud and adulteration. The World Health Organisation define foodborne disease as being the result of ingestion of foodstuffs contaminated with micro-organisms or chemicals (WHO, 2015). In this paper we consider food safety as encompassing this wider definition of harm caused by ingestion of food that is rendered harmful by a variety of means including presence of micro-organisms or chemicals or being affected by practices that could render the food harmful. There have been multiple incidents associated with the Chinese dairy sector including antibiotic contamination (year 2003); inadequate management of nutrition in infant formula (2004, 2005, 2012), recycling expired milk (2005), microbiological contamination (2005, 2008, 2011, 2012); melamine adulteration (2008); other illegal additions e.g. hydrolysed proteins (2009), detergent (2012); and mercury (2012) see Wu et al. (2018). One of the most notorious food safety incidents in China is the 2008 melamine in milk scandal. Raw milk was diluted (adulterated) by adding water and melamine and the resultant high levels of melamine in milk products killed six children and poisoned around 300,000 
consumers causing kidney stones and kidney failure (Pei et al. 2011; Holtkamp, Liu \& McGuire, 2014; WHO, 2018). As a result, domestic consumption of milk dropped significantly in China, product recalls were instituted and multiple countries prohibited the imports of all products containing Chinese milk powder (Xiu \& Klein, 2010; Ortega, Wang, Olynk, Wu \& Bai, 2011; Dong \& Li, 2016). At the time of the melamine incident, Chinese milk supply was based on 200 million farmers living in remote and underdeveloped regions of China with an average herd size of less than ten cows and the associated supply consolidation activities of a network of milk traders, and village milk supply stations (Gale \& Hu, 2009; Xiu \& Klein, 2010; Pavlovich, Sinha \& Rodrigues, 2016). The dairy sector has seen significant growth with the average annual milk consumption of Chinese citizens doubling between 2002 and 2014, requiring integration of the supply chain, and leading to China after India and the United States of America (USA) now being the third largest global milk producing country (Wu et al. 2018). Further, $\mathrm{Wu}$ et al. (2018) argue dairy products from a food safety perspective are high risk, easily contaminated at multiple steps in the supply chain and if not suitably processed and refrigerated subject to rapid microbiological spoilage. Thus making dairy products commodities of interest in this study.

Since the melamine incident, a decade ago, there is increasing focus on food safety governance in China and while the government is primarily responsible for controlling food safety, third-party bodies, especially news media, also contribute to wider governance structures (Cope et al. 2010; Zhang et al. 2015). In this context, governance encompasses "the culture and institutional environment in which citizens and stakeholders interact among themselves and participate in public affairs." (UNESCO, 2017). Governance is therefore more than simply describing the role of the government in food policy. Disclosure of information is an essential part of food safety governance (FAO \& WHO, 2003) and while the government is often the most trusted source, the majority of Chinese consumers still receive information on food safety incidents from the media (Jin \& Han, 2014; Peng, Li, Xia, Qi \& 
Li, 2015; Zhang, Xu, Oosterveer \& Mol, 2016). The sharp increase in Chinese media exposure of food safety incidents (Liu \& Ma, 2016) shows the media's role in food safety governance. However, there are several criticisms of their role for example, the potential for inaccuracy with media reports. In order to further improve food safety governance in China, it is arguably essential to understand the relationship between the government and the media in terms of the disclosure of information on food safety incidents and critique the efficacy of action. The aim of the research is to examine the role of news media in food safety governance in China specific emphasis on dairy products.

The paper is structured as follows: firstly a review of relevant literature in order to identify the research gap. Then, the methodology is explained, and the results presented, interpreted and discussed. Finally, conclusions and recommendations are made which should support the further development of food safety governance in China and the effective disclosure of food safety information.

\section{Evolving models of safety governance}

Globalisation of food supply chains, growing economic power of retailers, decreasing confidence in government regulation, emerging ethical concerns among consumers, and recurrent food safety incidents means that hybridisation of food governance has occurred in two dimensions: firstly the national and international dimension; and secondly between government, producers and third-party organisations (Zhang, Qiao, Wang, Pu, Yu \& Zheng, 2015; Verbruggen, 2016; Verbruggen \& Havinga, 2017). In this paper, the second dimension is the focus and specifically the role of government and third-party organisations in China.

\subsection{Official governance in China}

The Chinese regulatory food control system can be differentiated into: 1) food laws and regulations, 2) food control management, 3) inspection services, 4) laboratory services, and 5) information, education, communication and training (FAO \& WHO, 2003). Food laws and 
regulations can be divided into basic laws, subordinate laws and regulations, and provincial government regulations (Jia \& Jukes, 2013) see Figure 1. By referencing the latest regime changes, the enforcement structure in China is presented (Figure 2 see Chen, Wang \& Song, 2015) highlighting inspection is conducted by local government at province, city and county level and laboratory services are provided at both national and local levels (Jia \& Jukes, 2013).

\section{Take in Figures 1 and 2}

As an increasingly essential part of the food control regime, communication is assigned to all main departments that are responsible for food safety governance: the China Food and Drug Administration (CFDA), Ministry of Health (MOH), Ministry of Agriculture (MOA), and Administration of Quality Supervision, Inspection and Quarantine (AQSIQ) (FAO \& WHO, 2003; Jia \& Jukes, 2013; Zhou, 2017). Additionally, the information disclosure roles of each department are different (Figure 3).

\section{Take in Figure 3}

Whilst official food safety governance in China has improved significantly in past decades, problems still remain (Liu, 2010; Lam, Remais, Fung, Xu \& Sun, 2013; Holtkamp, Liu \& McGuire, 2014; Unnevehr \& Hoffmann, 2015). Suggested reasons for this include: unclear and overlapped responsibilities for different authorities (Liu, 2010; Holtkamp, Liu \& McGuire, 2014; Verbruggen \& Havinga, 2017); poor coordination and communication between departments and regions (Liu, 2010; Jia \& Jukes, 2013), lax enforcement (Pei et al. 2011; Yang, 2013), low penalties (Liang, 2011), inferior legal requirements (Jia \& Jukes, 2013; Yang, 2013); numerous small-scale producers (Peng, Li, Xia, Qi \& Li, 2015; Verbruggen \& Havinga, 2017), and fragmented consumer groups (Zhou, 2017). In this nexus, third-party governance began to develop. 
Third-party governance involves multiple stakeholders including the media, private standards owners and third-party certification, consumer associations, non-governmental organisations (NGOs) and industry associations (Zhang, Qiao, Wang, Pu, Yu \& Zheng, 2015). Media plays an important role in governance by exposing incidents and subsequently influencing the behaviour and attitude of government, food producers and consumers (Cope et al. 2010; Qiang, Wen, Jing \& Yue, 2011; Liu, Pieniak \& Verbeke, 2013; Mol, 2014; Peng, Li, Xia, Qi \& Li, 2015). By establishing governance standards, consumer associations contribute considerably to food safety governance (Zhang, Qiao, Wang, Pu, Yu \& Zheng, 2015). Moreover, there are several private third-party certification (TPC) standards, such as GlobalGAP (GAP = Good Agricultural Practice) and the British Retail Consortium (BRC) standard amongst others. TPC schemes address the independent certification of the management of elements of the food supply chain (Manning \& Soon, 2014) and can interface in a modular approach to provide whole assurance for a given supply chain (Manning, 2018). Some question the trustworthiness of TPC (Albersmeier, Schulze, Jahn \& Spiller, 2009) especially as part of a wider private-public governance structure (Turku, Lepistö \& Lundén, 2018). However, the use of TPC in China is restricted (Chen, Wang \& Song 2015; Kottenstede, 2017) and insufficient development of NGOs and industry associations mean their impact is negligible (Zhang, Qiao, Wang, Pu, Yu \& Zheng, 2015). Thus media reporting has a role to play, despite food safety governance still predominantly being driven by government (Chen, Wang \& Song, 2015).

\subsection{Transparency of governance}

Transparency through information disclosure reduces information asymmetry between consumers and powerful organisations, such as government and food enterprises, whereby one party has more information or knowledge than another (Mol, 2014; Pettinger, 2017). In 
China, food safety communication with consumers is undertaken through five official channels. These channels are: official information releases (most frequently used), whistleblowing hotlines (e.g.12315), free consultations from food safety experts working jointly with government, educational events (e.g. 'Food safety on campus' activities), and social media reports by official or semi-official accounts provided by the CFDA, MOH, MOA, and AQSIQ (Zhou, 2017). According to Food Safety Laws (FSL) (State Council of China, 2015), relevant departments disseminate information when certain food products are deemed unsafe, and failure to disclose will be punished through warning, demerit record, demotion or even dismissal based on the seriousness of circumstances. However, the current official information disclosure system is inhibited by a number of factors. Firstly, the large number of food producers in China means it is difficult for regulatory departments to collect complete food safety information, and consequently, they fail to make information immediately available to consumers on regular basis (Jia \& Jukes, 2013; Peng, Li, Xia, Qi \& Li, 2015; Zhou, 2017). Secondly, to maintain social stability and national image, release of information on food incidents can be delayed in a three-step approach consisting of supressing, framing and repressing (Lam, Remais, Fung, Xu \& Sun, 2013; Yang, 2013; Zhou, 2017). For instance, several months before the exposure of melamine scandal in 2008, while some state agencies received complaints from consumers, little information was released immediately, and subsequently, only positive information was mainly published (Yang, 2013). Thirdly, underreporting is common, especially for food-borne diseases with chronic and minor symptoms (Soon, Singh \& Baines, 2011; Lam, Remais, Fung, Xu \& Sun, 2013).

While government transparency may be limited in this regard, it does not mean that information disclosure systems functions poorly. Official departments are crucial in clarifying potentially false rumours, otherwise they may generate unnecessary scares and consequently social instability (Jia \& Jukes, 2013; Zhou, 2017). Fake news reports that have required clarification include fishermen using contraceptives to expedite growth of swamp eel (a 
species of fish in China), and McDonald's using genetically modified six-wing chickens for their products (CFDA, 2017). More importantly, studies found that most consumers regard the government as the most reliable source of information, even though they believed official information was underreported (Li et al. 2012; Liu, Pieniak \& Verbeke, 2013; Zhang, Xu, Oosterveer \& Mol, 2016).

There has been a sharp rise in food safety scandals reported by media (Mol, 2014; Liu \& Ma, 2016). In addition, according to WHO (2017), over $60 \%$ of outbreak reports arise from unofficial sources, especially online media, clenbuterol-contaminated pork and white sprite containing plasticizers were firstly revealed online (Zhang, Qiao, Wang, $\mathrm{Pu}, \mathrm{Yu} \&$ Zheng, 2015). Some Chinese consumers report that the media is their main source for receiving food safety related information (McCluskey \& Swinnen, 2011; Li et al. 2012; Jin \& Han, 2014). However when considering transparency, journalists may choose to expose or omit certain reports when disclosing (Veil \& Yang, 2012). For example, at the beginning of the melamine milk scandal, the company Sanlu mainly responsible for the incident, reached a deal with Baidu, the largest search engine in China, to delete the relevant negative online news (Zhang, Qiao, Wang, Pu, Yu \& Zheng, 2015; Huang, Wu \& Cheng, 2016). Secondly, due to the lack of employees with scientific background, media tends to acquire information from unreliable sources, exaggerate incidents and disseminate false information (Jia \& Jukes, 2013; Zhang, Qiao, Wang, Pu, Yu \& Zheng, 2015; Huang, Wu \& Cheng, 2016). Moreover, since the media, by and large, is influenced by the government (Stockmann \& Gallagher, 2011; Gehlbach \& Sonin, 2014; Yuan, 2016), disclosure may be limited and bias could occur. While these critiques in the literature have some value, since the reformation of the media in the 1980s, control has lessened considerably (Holtkamp, Liu \& McGuire, 2014; Babu, Aggarwal \& Chen, 2017). After the launch of Food Safety Laws by the State Council of China in 2009, food safety information is released without government intervention (Liu, Liu \& Gao, 2015). Additionally, the Chinese government tends to encourage the media to expose food safety 
scandals (Lu \& Wu, 2014; Zhang, Qiao, Wang, Pu, Yu \& Zheng, 2015), because of their low political sensitivity (Liu \& Ma, 2016).

Several studies use media reports in China as their data sources for research. Some looked at patterns of news media coverage only (Liu \& Ma, 2016; Zhang \& Xue, 2016). Others have compared the official reports against public news media reports (Holtkamp, Liu \& McGuire, 2014; Liu, Liu, Zhang \& Gao, 2015; Chen, Huang, Nong \& Kwan, 2016). Exploring patterns of news media coverage of food safety incidents in China, Zhang and Xue (2016) manually collected 2534 media reports (1553 incidents) for the period of 2004-2014 from nearly 40 news media, covering 32 provinces. They found that all food safety incidents were associated with economically motivated fraud or adulteration, which are very much linked to the level of industrialisation and urbanisation, i.e. that complex supply chains are becoming increasingly opaque. Economically developed provinces such as Guangdong, Beijing, Shandong, Zhejiang had the highest number of exposures. This finding concur with Liu and Ma (2016), who found the capital city of Guangdong, Beijing, Shandong and Zhejiang provinces had the highest number of reports of food scandals by analysing the reports collected by a team of 34 volunteers $(\mathrm{Wu}, 2011)$. Zhang and Xue (2016) also found that intentional distribution of contaminated products and artificial enhancement were the top fraud types reported. However in neither of these studies did the methodology seek to distinguish reports by source i.e. government sources and information sourced from public news reports. This research gap is considered in this paper to be of interest as the disclosure of information between different sources may be nuanced and driven by the particular motivations of the government and also the media which may, or may not be similar.

Studies examining differences between government reports and media reports observe differences in terms of the location or cause of the reported incident (Chen, Huang, Nong \& Kwan, 2016), quantity of reporting (Holtkamp, Liu \& McGuire, 2014; Liu, Liu, Zhang \& Gao, 2015), and original sources of reports (Liu, Liu, Zhang \& Gao, 2015). Comparing 
official and news media reports between 2006 and 2012 on food poisoning incidents (based on a database collected through web-crawler, $n=6701)$, Chen, Huang, Nong and Kwan (2016) found that official news reported higher home and school/company cafeterias food poisoning occurrences with microorganism (40\%) and animal, plant and fungi toxin (31\%) being the top causes, whilst news media report more cases occurred at cafeteria and restaurants, with top causes being man-made chemical hazards $(22 \%)$ or not clearly identified $(37 \%)$. The other two studies both rely on Wu's (2011) database. Holtkamp, Liu and McGuire (2014) analyse government and media reports between 2004 and 2011 across the whole country $(n=2107)$. They find that the number of food safety incidents reported by the media tended to be lower than by official departments. This nationwide trend concurs with Liu, Liu, Zhang and Gao (2015) who use the same database with a focus on Beijing only $(\mathrm{n}=295)$. They differentiate between incidents revealed by government and by news media and find that government reports $(n=150)$ are slighty more than those disclosed by news media only. They also find that consumers provide the information for $40 \%$ of the incidents reported, suggesting that the media could be a "chosen" information channel for consumers to highlight their complaints.

Findings from the above mentioned studies are based on incidents across all food categories and such data provides good insight into the patterns and trends of food scandals in China. However, it is difficult to assess the role public news media plays compared with official government reporting. Through comparing government and media reports on food safety incidents of a single category of products (dairy related), this study aims to examine the role of news media in food safety governance in China by considering four research questions:

\footnotetext{
Question 1: What were the quantity and nature of incidents exposed by the government and by media and how did this change over time?
}

Question 2: What were the origin of information, geographic location and the cause of the incidents reported by the government and by media?

\section{Question 3: What was the reporting timescale for incidents and did this vary} according to communication channel? 


\section{Question 4: How did the information compare and contrast between government reports and media reports?}

Dairy products were chosen because of the global role China plays in dairy production and due to the array of incidents that have occurred in the supply chain (see Wu et al. 2018). The research approach is now discussed.

\section{Material and methods}

The research took an inductive, longitudinal approach through directly comparing real life reporting of food safety incidents by government and news media over a 14-year period (2004-217). Holtkamp, Liy and McGuire (2014 p.459) suggest that "media data can be a valid source for scholars interested in studying food safety or other controversial topics in China" and this approach is used by Liu, Liu, Zhang and Gao (2015) in their research. Two online databases in relation to online media reports on food safety incidents are available in China. They are "Zhichuchuangwai (ZCCW)" (Wu, 2011) and Food Safety Information Database for Greater China (FSIDfGC) (Chen, Huang, Nong \& Kwan, 2016). A comparison of the two databases are presented in Table 1.

\section{Take in Table 1}

The data used in this study is from ZCCW. The database is considered as more appropriate for its representativeness of reporting online (Wu, 2011; Liu, Liu, Zhang \& Gao, 2015; Liu \& $\mathrm{Ma}, 2016)$, higher relevance to food safety incidents and longer period it covered. FSIDfGC is based on web-crawling using keywords. This means that the database contains reports not relevant to food safety incidents. For example, a search of "melamine" could include reports about policy, trend, scientific research reports, trade association reports and regulations whilst the ZCCW database is manually filtered for food safety incidents (Wu, 2011; Liu, Liu, Zhang \& Gao, 2015). We also test-searched on FSIDfGC some incidents that are included in ZCCW and failed to find them in FSIDfGC. This could be because some incidents were deleted from 
online search engines as reported by Zhang, Qiao, Wang, Pu, Yu and Zheng, (2015), hence could not have been included in FSIDfGC which was only completed in 2015, whilst the initial ZCCW database was completed in 2011 and then updated periodically (Wu, 2011; Liu \& Ma, 2016).

ZCCW has developed two lists of key words to facilitate online search of the database.

One list includes 1610 food names identified by the editors and the other list includes 2159 keywords indicating causes of food safety incidents (http://www.zccw.info/query). Those keywords were also adopted by Chen Huang, Nong and Kwan (2016) for FSIDfGC. In this study, out of the listed 2159 search terms, fifty-one were identified to be relevant to dairy products and dairy incidents (Figure 4). Full translation is provided in the Appendix. This generated 248 reports in the timeframe between 2004 and 2017. Fifteen reports were excluded because they were dairy product safety alerts or advice. Therefore, the total number of dairy safety incident related reports was 233. Although the database is supposed to include "uniquely identified" food safety incidents (Liu \& Ma, 2016, p. 105), some multiple reports were found of the same incidents. Further cleaning of the data resulted in the identification of 165 unique incidents.

Take in Figure 4

The reports were then subjected to thematic content analysis using NVivo 11 in line with the previously published methodology (see Liu, Liu, Zhang \& Gao, 2015). Although the reports were in Chinese, the coding was manual and in English. A structured coding system was initially generated from the literature and then iteratively developed by the first two authors (see Table 2). The coding was conducted by the first author and checked by the second author. The second author only recoded areas of disagreement. Therefore standard Kappa coefficient was not obtained. 
The results are now presented and analysed.

\section{Results and analysis}

In the dairy incidents dataset $(n=233)$, government reports were substantially fewer than media reports where media reports accounted $76.4 \%$ of the dataset $(n=178)$ with 24 incidents reported by both media and government and 27 incidents by government only.

\section{Question 1: What were the quantity and nature of incidents exposed by the government and by media and how did this change over time?}

\section{The reports are analysed by source/channel (Table 3) and by product type (Table 4).}

\section{Take in Tables 3 and 4}

The total number of incidents on milk powder $(\mathrm{n}=72)$ and fresh milk $(\mathrm{n}=57)$ is higher than other types. Specifically, incidents on milk powder (45.8\%) are most likely to be reported by both government and media. In addition, yogurt (16.7\%) and milk beverage (12.5\%) incidents are reported by both the government and media. The most frequent product incident reported by government is related to milk powder $(48.1 \%)$ and apart from milk powder $(42.1 \%)$, "media only" reported incidents were associated with fresh milk (43.9\%). For fresh milk related incidents, almost $90 \%$ were covered by the media and the media revealed an additional 33 more incidents with milk powder than with the government reporting.

\section{Question 2: What were the origin of information, geographic location and the cause of} the incidents reported by the government and by media?

\subsection{Causes of incidents}

The causes of incidents are divided into ten categories: non-food raw materials found in dairy products e.g. melamine in milk powder; counterfeit products; microbial contamination; foreign bodies such as hair; additives which did not comply with food safety standards including preservatives; insects contamination such as maggots; out of date/expired products; 
dairy products that were reprocessed from inferior materials; nutritional non-compliance e.g. insufficient protein content; with other causes accounting for only a very small percentage of reports (Table 5).

\section{Take in Table 5}

The causes of incidents include both food safety (microbial or foreign body contamination), food fraud issues such as counterfeit product and misrepresentation that may, or may not, have health implications. Interestingly foreign body contamination, and insect contamination are only reported in the media. Sixty-nine percent of the incidents are reported in the "media only", compared with government only $(16,4 \%)$ and both media and government (14.5\%). This highlights the role of the media in information disclosure to the Chinese population.

\subsection{Geographic location (province)}

Table 6 compares the provinces where the incidents occurred. Provinces with six or more reports published on food safety incidents are listed separately. Provinces with fewer than six incidents are labelled as "other provinces". When the same incidents occur in several provinces, they are labelled as "multiple provinces" incidents. Multiple provinces reported the highest incidence $(\mathrm{n}=41[65 \%])$ followed by those in Guangdong $(12.7 \%)$. Both government and media tended to report incidents occurring in multiple provinces, Guangdong and Shanghai. The number of the reports in some provinces (Zhejiang, Beijing, Guangxi, Hebei, Shandong, Henan and Jiangsu) is only one or zero. Government only reports tend to expose incidents in multiple provinces (29.6\%), Guangdong (18.5\%), and Beijing (14.8\%). In terms of incidents exposed by "media only", they are more likely to occur in multiple provinces $(22.8 \%)$

\section{Take in Table 6}


Additionally, the proportion of incidents in Guangdong, Zhejiang, Shanghai and Beijing is also high, with each accounting for approximately 10\%. Moreover, the number of media reports in all other provinces was fewer than six in each case. However within this analysis it should be noted that although the number of media reports in Guangxi was ten, all these reports were about one incident namely farmers adding chlorine dioxide into fresh milk to extend shelf-life. By contrast, some types of incidents were generally reported only once. Therefore it is important not to translate the frequency of reports directly as a means to identify the frequency of actual incidents.

\subsection{Physical location that incidents occurred}

The physical locations where the reported dairy related incidents occurred are divided into six categories: home; factories; farms; retailers/supermarkets; stores and local street shops; schools; and not specified, i.e. where the location is not mentioned in the incident reports. The incidents without specified physical location was the largest group (58.1\%), followed by those occurring at home $(29.7 \%)$. Incidents occurring at schools $(1.8 \%)$ are the least likely to be reported by all channels (Table 7). The majority of government reports did not mention location (96.3\%), compared to only $4.2 \%$ where location was not identified by "media only" reports. This is an interesting difference between the two channels.

\section{Take in Table 7}

While "media only" reports exposed forty-six incidents at home, only one incident is reported by government only reports. All incidents reported as occurring in factories, farms, retailers and schools are exposed by the "media only" although proportionately each of these categories is below $7 \%$ of the total. In the media reports incidents occurring in factories and without specified locations tend to be reported several times with two factory located incidents being identified in 14 reports. One example identified shows producers extracting proteins from disposed of leather shoes or sofas and adding them to milk powder in order for 
defective products to pass analytical tests for protein content. The other incident highlights a dairy company mixing in-date and expired milk powder, then re-selling those products to consumers.

Other areas included in the reporting information are: identification of government response, risk communication about the incident, e.g. the negative effects of ingesting melamine or how to recognise counterfeit products; information linking with previous incidents; introducing the corrective action by dairy companies which included both positive and negative comment; comments on the government, e.g. complaints on weak response by local government; market research to gain opinions from consumers or investigate whether unsafe products were still sold by retailers (Table 8).

\section{Take in Table 8}

Media reports are more likely to include educational content about the incidents $(33.1 \%)$. Furthermore, media reports provide information about linkages with previous incidents (20.2\%), government reaction $(19.7 \%)$, dairy company reaction $(16.3 \%)$, comments on the government (12.9\%), suggestions (8.4\%) and market research $(8.4 \%)$.

\section{Question 3: What was the reporting timescale for incidents and did this vary according} to communication channel?

Of the 24 incidents exposed by both government and media, almost $90 \%(n=21)$ are exposed first by the government, and only three are reported earlier by the media. Table 9 shows the feature of incidents exposed by both government and media.

\section{Take in Table 9}

In terms of product types, the incidents reported earlier by government are more likely to be milk powder. However, it should be noted that due to the small number of incidents discussed here, generalisations are not possible. Differences in reporting channel between geographic 
location and causes are not substantial, especially as over $90 \%$ of the earlier incidents revealed by government did not specify geographic location and all incidents reported earlier by the media occurred in multiple areas. Figure 5 shows that the total number of incidents exposed was the highest in 2005 and 2012. In 2005, 37 incidents were reported 51 times. In 2012, 29 incidents were reported 63 times. As shown in Figure 4, milk power and fresh milk were affected most. Top causes reported in 2005 were substandard nutrition and counterfeit products whilst in 2012 product adulteration and microbial contamination were reported most. Strikingly, very few or no incidents were reported in 2004, 2010, and between 2014 and 2017. The government exposed the highest number of incidents in 2005 , with eight incidents being exposed, however, the number for other years is fewer than five (Figure 6). The incidents uncovered by media only in 2005, 2011, 2012 and 2013 are more than other years, being all above 15. Additionally, there is also a noticeable increase in 2009 before a sharp decrease in 2010.

\section{Take in Figures 4, 5 and 6}

Comparatively in most the years, "media only" highlight more incidents than the government alone. This is particularly true for 2005 and 2012. In 2005, while "media only" reported 23 incidents, government alone only exposed eight. In 2012, "media only" revealed 21 incidents, nevertheless, only two were exposed government alone.

\section{Question 4: How did the information compare and contrast between government}

\section{reports and media reports?}

From 2004 to 2017 , only twenty-four of the safety incidents $(n=165)$ were reported by both government and media. This shows the degree of differentiation between the two reporting systems with the government alone revealing twenty-seven incidents. Without the media reporting, consumers would be unaware of the additional incidents. This finding here is in contrast with Holtkamp, Liu and McGuire (2014) and Liu, Liu and Gao (2015) who found 
that the government tended to report more incidents than the media. One possible explanation

430 for this difference is that the previous research covers all food categories, while this study only focuses on dairy products. Additionally, considering that 2009 is a milestone in China

432

\section{Discussion}

China has witnessed a sharp increase in reported food safety incidents, which has not only raised concerns among Chinese consumers, but also damaged the international reputation of Chinese food industry (Jia \& Jukes, 2013; Peng, Li, Xia, Qi \& Li, 2015; Liu \& Ma, 2016). To improve this situation, official food safety systems has been reformed, and third-party stakeholders, especially news media, have played an increasingly important role in the governance of food safety (Jia \& Jukes, 2013; Zhang, Qiao, Wang, Pu, Yu \& Zheng, 2015). To protect public health, communicating food safety risk in a timely way is essential (Wright, 2016). Therefore, channels that provide early warning of incidents can play a more important role in food safety governance. Food incidents impact on human health and erode consumer trust (Elliott Review, 2014). Information disclosure and transparency increase consumer trust (Mol, 2014). Consumers perceptions of food safety risk is dependent on the information they receive, its source and then how they cognitively frame the message to inform trust (Liu, Pieniak \& Verbeke, 2014) who found that after the television the internet was the second most frequent channel used by consumers for information about food safety. This study found food producers to be the least trusted, a neutral level of trust in government information and greatest levels of trust in consumer associations, research institutes, relatives and friends.

The role of the media as an information source and more widely as an actor in food safety governance is considered here and increasing public attention towards the safety of 
dairy products in China may have contributed to the greater reporting of incidents by consumers direct to the media. Government reported incidents are based on official inspections, which indicates that Chinese government tends to only trust its own inspections as has been suggested by some want to ensure that all reports are verified before release (Jia \& Jukes, 2013; Zhou, 2017). In contrast, the media relies heavily on collecting information from a wide range of sources, but the reliability of the information provided by such sources is arguably difficult to validate and thus the interpretation of such data should be undertaken with caution. The fact that no media reports are identified as being sourced from official inspections suggests that the government tends not to share their information with the media concurring with the study of Liu, Liu and Gao (2015). Although the number of incidents sourced from trade associations and dairy companies was extremely low, these incidents are more likely to be reported multiple times perhaps because the media felt they had greater reliability.

Milk powder is the most reported incident, although the influence of purposive regulatory sampling should be considered (see Kowalska, Manning \& Soon, 2018). In the "media only" incidents there is a strong focus on fresh milk, probably as a result of the shorter shelf-life as out of date/expired products were the mostly commonly reported problem. A focus in this research on incident types adds to the current literature, since no previous study has compared the type of reported incident with a specific focus to the dairy products. Apart from microbial contamination, which is heavily reported by the government, the media also exposes substandard nutrition and counterfeit products frequently as did Chen, Huang, Nong and Kwan (2016). However in contrast the results from this study did not highlight animal, plant or fungi toxin and food additives as frequently reported issues probably ue to the product type. For example, there is no regulation on pesticides and veterinary drug residues for dairy products in China, since the government only controls this issue through monitoring animal feeds (NHCPRC, 2013). Interestingly "media only" reported incidents are related to 
expired products, foreign body and insect contamination perhaps explained by the heavy reliance of media on consumers as the information source. It should be noted that government reports did not focus on foreign body or insect contamination.

This study is novel in examining the provinces where dairy incidents occur and interestingly most incidents reported by government do not identify the physical location where the incident occurs, but perhaps that is because the product has already been removed from sale and is not seen to pose a risk thus the location is not identified. In media reports, the home was the most frequently reported contradicting McCarthy, Brennan, De Boer and Ritson (2008) and Chen, Huang, Nong and Kwan (2016) who state that the media tended to report incidents that happen in public areas. The majority of government reports mention the reaction of the government, which is not surprising, as the government seeks to show its responsible behaviour to the public. Most media reports include educational information about the incidents, link the incidents with previous incidents and introduce the reactions of the government and dairy companies. Specially, areas of information comprising previous incidents, comments on government activity, and market research are only included in media reports. With more variety and a larger amount of information included in media reports, it is possible for consumers to gain more understanding of an incident. These results support the work of McCarthy, Brennan, De Boer and Ritson (2008) and Shan et al. (2014), and extent their findings to identify additional information provided to the public. The timing of reports identified in this study agrees with Shan et al. (2014) that the government exposes incidents earlier than the media.

Through analysing the government and media reports on dairy related food safety incidents reported between 2004 and 2017, differences were found between government reporting and media reporting. This research shows that the media plays a complementary role in food safety governance in China. Firstly, the media exposed more incidents than the government, with 114 reported only by media, 27 only by government and 24 by both 
government and media. Owing to the small number of incidents exposed by both government and media in this study, no conclusions can be drawn on dual reporting. However, since this comparison can contribute to a better understanding of the role of media in food safety governance further empirical work should be undertaken in this area.

\section{Conclusion}

Using dairy products as the food item of interest, the aim of the research was to explore the role of the media in food safety governance in China. Thematic content analysis was used to evaluate government and news media reports on dairy related food safety incidents in China between 2004 and 2017. However it should be noted that some original websites hyperlinked on ZCCW cannot be accessed now, making it impossible to evaluate the quality and validity of all the data, which is a limitation on this study. The small dataset examined here means that only preliminary findings can be presented and further studies with a larger dataset need to be undertaken to confirm the results can be further generalised. The government performed better on exposing incidents earlier within the 14-year period but the news media played a complementary role in food safety governance exposing a wider coverage of incidents especially those identified in the home. This is particularly so after 2009 when adulteration and contamination incidents were reported more widely by media. This study extends the current literature on the role of the news media in food safety governance in China by focusing on a single food sector (dairy), but on a national scale, and also considering the physical location where the incident has occurred. The contribution this paper makes to existing literature is to address the role of media reporting of food incidents in wider food safety governance. As supply chains become more global and complex, effective risk communication is essential. It is important that emerging models of risk communication are considered and critiqued in order to ensure that consumers can readily access information about the food they consume. Although this research has focused on dairy sector specifically the work has provided a some understanding that could be extended to other food categories. 
News media alone was considered in this research. However, social media has played an

533 increasingly important role in food safety governance, hence, it would be helpful for further research to investigate role of social media in food safety governance. Therefore, further studies are suggested to investigate a wider range of media exposure to reflect the role of media in food safety governance in China more comprehensively.

\section{References}

Albersmeier, F., Schulze, H., Jahn, G \& Spiller, A. (2009), The reliability of third-party certification in the food chain: from checklists to risk-oriented auditing, Food Control, 20(10), 927-935.

Babu, S.C., Aggarwal, S \& Chen, J. (2017). Role of media in shaping the policy process: Comparative lessons from the food price crisis in Bangladesh, China, India, and Vietnam.

544 [Online]. International Food Policy Research Institute. Available from: 545 http://www.ifpri.org/publication/role-media-shaping-policy-process-comparative-lessons-

546 food-price-crisis-bangladesh-china Accessed 28 December 2017.

547 CFDA (China Food and Drug Administration). (2017). A collection of recent food and drug 548 related rumour (No.2). [Online]. CFDA. Available from: 549 http://www.sda.gov.cn/WS01/CL1978/171963.html. Accessed 04 December 2017.

550 Chen, S., Huang, D., Nong, W \& Kwan, H.S. (2016). Development of a food safety 551 information database for Greater China. Food Control, 65, 54-62.

552 Chen, K., Wang, X.X \& Song, H.Y. (2015). Food safety regulatory systems in Europe and 553 China: A study of how co-regulation can improve regulatory effectiveness. Journal of 554 Integrative Agriculture, 14(11), 2203-2217

555 Codex Alimentarius. 2011. Milk and milk products. $2^{\text {nd }}$ ed. Rome: (Food and Agriculture 556 Organisation) and WHO (World Health Organisation).

557 Cope, S., Frewer, L.J., Houghton, J., Rowe, G., Fischer, A.R.H \& de Jonge, J. (2010). 558 Consumer perceptions of best practice in food risk communication and management: 559 Implications for risk analysis policy. Food Policy, 35(4), 349-357.

560 Dong, X \& Li, Z. (2016). Food safety issues in China: A case study of the dairy 561 sector. Journal of the Science of Food and Agriculture, 96(1), 346-352.

562 Elliott Review into the Integrity and Assurance of Food Supply Networks (2014). Final 563 Report A National Food Crime Prevention Framework July 2014. HM Government. London

564 FAO (Food and Agriculture Organization) and WHO (World Health Organisation). 2003. 565 Assuring food safety and quality: guidelines for strengthening national food control system. 
(FAO Food and Nutrition Paper 76). Rome: Food and Agriculture Organisation and World Health Organisation.

State Council of China. (2015). The Food Safety Law of the People's Republic of China. [Online]. Available from http://www.gov.cn/zhengce/2015-04/25/content_2853643.htm (in Chinese). Last accessed 25 June 2018.

State Council of China. (2009). The Food Safety Law of the People's Republic of China. [2009-02-28]. [Online]. Available from http://www.gov.cn/flfg/200902/28/content_1246367.htm (in Chinese). Last accessed 25 June 2018.

Gale, F \& Hu, D. (2009), "Supply chain issues in China's milk adulteration incident”, The International Association of Agricultural Economic Conference, Beijing, August 16-22.

Gehlbach, S \& Sonin, K. (2014). Government control of the media. Journal of Public Economics, 118, 163-171.

Holtkamp, N., Liu, P \& McGuire, W. (2014). Regional patterns of food safety in China: What can we learn from media data? China Economic Review, 30, 459-468.

Huang, Y., Wu, F \& Cheng, Y. (2016). Crisis communication in context: Cultural and political influences underpinning Chinese public relations practice. Public Relations Review, 42(1), 201-213.

Jia, C \& Jukes, D. 2013. The national food safety control system of China - a systematic review. Food Control, 32(1), pp.236-245.

Jin, H.J \& Han, D.H. (2014). Interaction between message framing and consumers' prior subjective knowledge regarding food safety issues. Food Policy, 44, 95-102.

Kottenstede, K. (2017). Transnational private food standards in the People's Republic: Hybridization with Chinese characteristics. In: Verbruggen, P. and Havinga, T. ed. Hybridization of food governance: trends, types and results. Cheltenham: Edward Elgar Publishing. pp. 215-239.

Kowalska, A., Soon, J.M., and Manning, L. (2018). A study on adulteration in cereals and bakery products from Poland including a review of definitions Food Control, 92, 348-356

Lam, H.M., Remais, J., Fung, M.C., Xu, L \& Sun, S.S.M. (2013). Food supply and food safety issues in China. The Lancet, 381(9882), 2044-2053.

Li, D., Nanseki, T., Takeuchi, S., Song, M., Chen, T \& Zhou, H. (2012). Consumer Perceptions upon Food Safety and Demographic Determinants in China: Empirical Analysis based on a Survey of 512 Respondents. J. Fac. Agr., Kyushu Univ, 57(2), 517-525.

Liang, J. (2011). Increasing the intensity of management of food safety in those large-scale food enterprises. Jingchu Website, 14 April, [Online]. Jingchu Website. Available from: http://focus.cnhubei.com/original/201104/t1671057.shtml [Accessed 26 November 2017].

Liu, P \& Ma, L. (2016). Food scandals, media exposure, and citizens' safety concerns: A multilevel analysis across Chinese cities. Food Policy, 63, 102-111. 
Liu, F., Liu, Y \& Gao, J. (2015). Food safety incidents in Beijing: occurrence patterns, causes and wider social implications. Palgrave Communications, 1. [Online]. Palgrave. Available from: https://www.nature.com/articles/palcomms201529.pdf [Accessed 16 November 2017].

Liu, Y., Liu, F., Zhang, J \& Gao, J. (2015). Insights into the nature of food safety issues in Beijing through content analysis of an Internet database of food safety incidents in China. Food Control, 51, pp.206-211.

Liu, R., Pieniak, Z \& Verbeke, W. (2014). Food-related hazards in China: Consumers' perceptions of risk and trust in information sources. Food Control, 46, 291-298.

Liu, R., Pieniak, Z \& Verbeke, W. (2013). Consumers' attitudes and behaviour towards safe food in China: A review. Food Control, 33(1), 93-104.

Liu, P. (2010). Tracing and periodising China's food safety regulation: A study on China's food safety regime change. Regulation \& Governance, 4(2), 244-260.

Lu, F \& Wu, X. (2014). China food safety hits the "gutter". Food Control, 41, 134-138.

Manning, L. (2018), Triangulation: effective verification of food safety and quality management systems and associated organisational culture World Hospitality and Tourism Themes 10(3), 297-312

Manning, L \& Soon, J.M, (2014). Developing systems to control food adulteration, Food Policy, 49(1), 23-32

McCarthy, M., Brennan, M., De Boer, M \& Ritson, C. (2008). Media risk communicationwhat was said by whom and how was it interpreted. Journal of Risk Research, 11(3), 375394.

McCluskey, J \& Swinnen, J. (2011). The media and food risk perceptions. EMBO reports, 12(7), 624-629.

Mol, A.P. (2014). Governing China's food quality through transparency: a review. Food Control, 43, 49-56.

NHCPRC (National Health Commission of the People's Republic of China). 2013. Answers to the questions about the standards on dairy products. [Online]. NHCPRC. Available from: http://www.nhfpc.gov.cn/zwgk/zswd/201306/1d5f7a29e2a14ae59aeee704fc11b2b0.shtml [Accessed 20 April 2018].

Ortega, D.L., Wang, H.H., Olynk, N.J., Wu, L \& Bai, J. (2011). Chinese consumers' demand for food safety attributes: A push for government and industry regulations. American Journal of Agricultural Economics, 94(2), 489-495.

Pavlovich, K., Sinha, P. N \& Rodrigues, M. (2016). A qualitative case study of MNE legitimacy: The Fonterra-Sanlu IJV corporate milk scandal in China. International Journal of Emerging Markets, 11(1), 42-56.

Pei, X., Tandon, A., Alldrick, A., Giorgi, L., Huang, W \& Yang, R. (2011). The China melamine milk scandal and its implications for food safety regulation. Food Policy, 36, 412420. 
Peng, Y., Li, J., Xia, H., Qi, S \& Li, J. (2015). The effects of food safety issues released by we media on consumers' awareness and purchasing behaviour: A case study in China. Food Policy, 51, 44-52.

Pettinger, T. (2017). Asymmetric information problem. [Online]. Economics help. Available from: https://www.economicshelp.org/blog/glossary/asymmetric-information/ Accessed 10 December 2017.

Qiang, L., Wen, L., Jing, W \& Yue, D. (2011). Application of content analysis in food safety reports on the Internet in China. Food Control, 22(2), 252-256.

Shan, L., Regan, Á., De Brún, A., Barnett, J., van der Sanden, M.C., Wall, P \& McConnon, Á. (2014). Food crisis coverage by social and traditional media: A case study of the 2008 Irish dioxin crisis. Public Understanding of Science, 23(8), 911-928.

Soon, J.M., Singh, H \& Baines, R. (2011). Foodborne diseases in Malaysia: A review. Food Control, 22(6), 823-830.

Stockmann, D \& Gallagher, M.E. (2011). Remote control: How the media sustain authoritarian rule in China. Comparative Political Studies, 44(4), 436-467.

Turku, M., Lepistö, O \& Lundén, J. (2018). Differences between official inspections and third party audits of food establishments, Food Control, 85, 459-465.

UNESCO (United Nations Educational, Scientific and Cultural Organisation). 2017. Concept of governance. [Online]. UNESCO. Available from:

http://www.unesco.org/new/en/education/themes/strengthening-education-systems/qualityframework/technical-notes/concept-of-governance/ [Accessed 13 January 2018].

Unnevehr, L \& Hoffmann, V. (2015). Food safety management and regulation: International experiences and lessons for China. Journal of Integrative Agriculture, 14(11), 2218-2230.

Veil, S.R \& Yang, A. (2012). Media manipulation in the Sanlu milk contamination crisis. Public Relations Review, 38(5), 935-937.

Verbruggen, P \& Havinga, T. (2017). Hybridization of food governance: An analytical frameworl. In: Verbruggen, P. and Havinga, T. ed. Hybridization of food governance: trends, types and results. Cheltenham: Edward Elgar Publishing. pp. 1-27.

Verbruggen, P. (2016). Understanding the New Governance of Food Safety: Regulatory Enrolment as a Response to Change in Public and Private Power. Cambridge J. Int'l \& Comp. L., 5, p.418.

WHO (World Health Organisation). (2018). Questions and answers on melamine. [Online]. WHO. Available from: http://www.who.int/csr/media/faq/QAmelamine/en/ [Accessed 13 January 2018].

WHO (World Health Organisation). (2017). Epidemic intelligence - systematic event detection. [Online]. WHO. Available from: http://www.who.int/csr/alertresponse/epidemicintelligence/en/ Accessed 05 December 2017.

WHO (World Health Organisation). (2015). Health topics - Foodborne diseases. [Online]. Available from: http://www.who.int/topics/foodborne_diseases/en/ Accessed 13 August 2018. 
Wright, M.S. (2016). Manufacturing food safety incidents and the role of food safety culture.

686

687

688

689

690

691

692

693

694

695

696

697

698

699

700

701

702

703

704

705

706

707

708

709

710

711

712

713

714

715

716
In: Soon, J.M., Manning, L. and Wallace, C.A. ed. Foodborne diseases: case studies of out breaks in the agri-food industries. Boca Raton: CRC Press.

Wu, X., Lu, Y., Xu, H., Lv, M., Hu, D., He, Z., Liu, L., Wang, Z \& Feng, Y., (2018). Challenges to improve the safety of dairy products in China. Trends in Food Science \& Technology, 76, 6-14

Wu, H. (2011). Yi fen xiang shi. Zhongguo shipin anquan zhuangkuang diaocha. Working Paper (http://www.zccw.info/report. Accessed 10 June 2018.

Xiu, C \& Klein, K.K. (2010). Melamine in milk products in China: examining the factors that led to deliberate use of the contaminant. Food Policy, 35(5), 463-470.

Yang, G. (2013). Contesting food safety in the Chinese media: Between hegemony and counter-hegemony. The China Quarterly, 214, 337-355.

Young, M. N., Peng, M. W., Ahlstrom, D., Bruton, G. D \& Jiang, Y. (2008). Corporate governance in emerging economies: A review of the principal-principal perspective. Journal of management studies, 45(1), 196-220.

Yuan, H. (2016). Measuring media bias in China. China Economic Review, 38, 49-59.

ZCCW (Zhichuchuangwai). (2011). The research of Chinese food safety condition (2004 2011). [Online]. ZCCW. Available from: http://www.zccw.info/report [Accessed 10 April 2018].

ZCCW (Zhichuchuangwai). (Not dated). Online searching. [Online]. ZCCW. Available from: http://www.zccw.info/query [Accessed 40 April 2018].

Zhang, L., Xu, Y., Oosterveer, P \& Mol, A.P. (2016). Consumer trust in different food provisioning schemes: evidence from Beijing, China. Journal of Cleaner Production, 134, 269-279.

Zhang, W \& Xue, J. (2016). Economically motivated food fraud and adulteration in China: An analysis based on 1553 media reports. Food Control, 67, 192-198.

Zhang, M., Qiao, H., Wang, X., Pu, M., Yu, Z \& Zheng, F. (2015). The third-party regulation on food safety in China: A review. Journal of Integrative Agriculture, 14(11), 2176-2188.

Zhou, G. (2017). The regulatory regime of food safety in China: Governance and segmentation. Basingstoke: Palgrave Macmillan. 
List of Abbreviations used in the paper

\begin{tabular}{l|l}
\hline Abbreviations & \\
\hline AQSIQ & Administration of Quality Supervision, Inspection and Quarantine \\
\hline BRC & British Retail Consortium \\
\hline CFDA & China Food and Drug Administration \\
\hline FSL & Food Safety Laws \\
\hline GAP. & Good Agricultural Practices \\
\hline MOA & Ministry of Agriculture \\
\hline MOH & Ministry of Health \\
\hline NFSC & National Food Safety Commission \\
\hline NGOs & Non-Governmental Organisations \\
\hline ZCCPRC & National Health Commission of the People's republic of China \\
\hline & Zhichuchuangwai (the database)
\end{tabular}

719 
Table 1. Comparison of databases of reports on food incidents in China

\begin{tabular}{|c|c|c|}
\hline & Zhichuchuangwai (ZCCW) & $\begin{array}{l}\text { Food Safety Information Database for } \\
\text { Greater China (FSIDfGC) }\end{array}$ \\
\hline Web address & http://www.zccw.info & http://kwanlab.bio.cuhk.edu.hk/FS/ \\
\hline Year database was launched & 2011 & 2015 \\
\hline Geographical area covered & Mainland China & $\begin{array}{l}\text { Greater China (China, Hong Kong, } \\
\text { Macau and Taiwan) }\end{array}$ \\
\hline Methods of data collection & Manual & Web-crawling \\
\hline $\begin{array}{l}\text { Relevance to food safety } \\
\text { incidents }\end{array}$ & $\begin{array}{l}\text { Filtered to include only reports } \\
\text { on food safety incidents) }\end{array}$ & $\begin{array}{l}\text { May include information about food } \\
\text { safety incidents as well as policy, } \\
\text { trend, scientific research reports, } \\
\text { trade association reports and } \\
\text { regulations) }\end{array}$ \\
\hline $\begin{array}{l}\text { Number of reports on food } \\
\text { safety incidents included }\end{array}$ & $\begin{array}{l}2107 \text { (between } 2004 \text { and 2011) } \\
3500 \text { (between } 2004 \text { and 2017) }\end{array}$ & Not available \\
\hline
\end{tabular}

722 
Table 2. Levels of coding and sources of codes

\begin{tabular}{|c|c|c|}
\hline Level 1 & Level 2 & Source(s) \\
\hline \multirow{2}{*}{$\begin{array}{l}\text { Original } \\
\text { sources of } \\
\text { information }\end{array}$} & $\begin{array}{l}\text { Government inspections } \\
\text { Media instigated by consumers } \\
\text { Media instigated by government } \\
\text { Media instigated by journalists }\end{array}$ & Liu, Liu, Zhang \& Gao, (2015) \\
\hline & $\begin{array}{l}\text { Media instigated by trade associations } \\
\text { Media instigated by dairy companies } \\
\text { Other sources }\end{array}$ & Authors' own \\
\hline Types & $\begin{array}{l}\text { Milk powder } \\
\text { Fresh milk } \\
\text { Milk beverage } \\
\text { Yogurt } \\
\text { Cheese and cream } \\
\text { Other dairy products }\end{array}$ & ZCCW (not dated) \\
\hline \multirow[t]{2}{*}{ Causes } & $\begin{array}{l}\text { Microbial contamination } \\
\text { Substandard nutrition } \\
\text { Non-food raw material contamination } \\
\text { Foreign bodies (debris) } \\
\text { Food additives } \\
\text { Reprocessed products } \\
\text { Others }\end{array}$ & Liu, Liu, Zhang \& Gao, (2015) \\
\hline & $\begin{array}{l}\text { Counterfeit products (fake) } \\
\text { Out of date/expired products } \\
\text { Insect contamination }\end{array}$ & Authors' own \\
\hline Provinces & \multicolumn{2}{|c|}{$\begin{array}{l}\text { There are } 34 \text { provinces in China. No previous study has compared the provinces of incidents. } \\
\text { Hence, this research is the first to compare the nature of incidents by provinces. }\end{array}$} \\
\hline \multirow{3}{*}{ Location } & Home & $\begin{array}{l}\text { McCarthy, Brennan, De Boer \& Ritson } \\
\text { (2008) / Chen, Huang, Nong \& Kwan, } \\
(2016)\end{array}$ \\
\hline & Schools & Chen, Huang, Nong \& Kwan, (2016) \\
\hline & $\begin{array}{l}\text { Not specified } \\
\text { Factories } \\
\text { Farms } \\
\text { Retailers } \\
\end{array}$ & Authors' own \\
\hline $\begin{array}{l}\text { Other areas of } \\
\text { information } \\
\text { included }\end{array}$ & $\begin{array}{l}\text { Reaction of the government } \\
\text { Knowledge about the incidents } \\
\text { Linking with previous incidents } \\
\text { Reaction of dairy companies } \\
\text { Comments on the government } \\
\text { Suggestions for consumers } \\
\text { Market research } \\
\text { Others }\end{array}$ & $\begin{array}{l}\text { Authors' own } \\
\text { (This research is the first to compare other } \\
\text { areas of information included.) }\end{array}$ \\
\hline
\end{tabular}


Table 3. The original sources of information on dairy related food safety incidents vs types of channels

\begin{tabular}{|c|c|c|c|c|c|}
\hline $\begin{array}{l}\text { Information } \\
\text { source }\end{array}$ & & $\begin{array}{l}\text { Both } \\
\text { government } \\
\text { and media }\end{array}$ & $\begin{array}{l}\text { Government } \\
\text { only }\end{array}$ & Media only & $\begin{array}{l}\text { Total } \\
\text { incidents } \\
\text { (Total } \\
\text { reports) }\end{array}$ \\
\hline $\begin{array}{l}\text { Government } \\
\text { inspections }\end{array}$ & $\begin{array}{l}\text { Count } \\
\% \text { within the source } \\
\% \text { within incidents published } \\
\text { by the channel }\end{array}$ & $\begin{array}{l}22 \\
44.9 \% \\
91.7 \%\end{array}$ & $\begin{array}{l}27 \\
56.3 \% \\
100.0 \%\end{array}$ & $\begin{array}{l}0 \\
0.0 \% \\
0.0 \%\end{array}$ & $\begin{array}{l}49(55) \\
100.0 \% \\
29.7 \%\end{array}$ \\
\hline $\begin{array}{l}\text { Media } \\
\text { instigated by } \\
\text { consumers }\end{array}$ & $\begin{array}{l}\text { Count } \\
\% \text { within the source } \\
\% \text { within incidents published } \\
\text { by the channel }\end{array}$ & $\begin{array}{l}0 \\
0.0 \% \\
0.0 \%\end{array}$ & $\begin{array}{l}0 \\
0.0 \% \\
0.0 \%\end{array}$ & $\begin{array}{l}50 \\
100.0 \% \\
43.9 \%\end{array}$ & $\begin{array}{l}50(59) \\
100.0 \% \\
30.3 \%\end{array}$ \\
\hline $\begin{array}{l}\text { Media } \\
\text { instigated by } \\
\text { government }\end{array}$ & $\begin{array}{l}\text { Count } \\
\% \text { within the source } \\
\% \text { within incidents published } \\
\text { by the channel }\end{array}$ & $\begin{array}{l}2 \\
7.4 \% \\
8.3 \%\end{array}$ & $\begin{array}{l}0 \\
0.0 \% \\
0.0 \%\end{array}$ & $\begin{array}{l}25 \\
92.6 \% \\
21.9 \%\end{array}$ & $\begin{array}{l}27(39) \\
100.0 \% \\
16.4 \%\end{array}$ \\
\hline $\begin{array}{l}\text { Media } \\
\text { instigated by } \\
\text { journalists }\end{array}$ & $\begin{array}{l}\text { Count } \\
\% \text { within the source } \\
\% \text { within incidents published } \\
\text { by the channel }\end{array}$ & $\begin{array}{l}0 \\
0.0 \% \\
0.0 \%\end{array}$ & $\begin{array}{l}0 \\
0.0 \% \\
0.0 \%\end{array}$ & $\begin{array}{l}23 \\
100.0 \% \\
20.2 \%\end{array}$ & $\begin{array}{l}23(33) \\
100.0 \% \\
13.9 \%\end{array}$ \\
\hline $\begin{array}{l}\text { Media } \\
\text { instigated by } \\
\text { trade } \\
\text { associations }\end{array}$ & $\begin{array}{l}\text { Count } \\
\% \text { within the source } \\
\% \text { within incidents published } \\
\text { by the channel }\end{array}$ & $\begin{array}{l}0 \\
0.0 \% \\
0.0 \%\end{array}$ & $\begin{array}{l}0 \\
0.0 \% \\
0.0 \%\end{array}$ & $\begin{array}{l}7 \\
100.0 \% \\
6.1 \%\end{array}$ & $\begin{array}{l}7(21) \\
100.0 \% \\
4.2 \%\end{array}$ \\
\hline $\begin{array}{l}\text { Media } \\
\text { instigated by } \\
\text { dairy companies }\end{array}$ & $\begin{array}{l}\text { Count } \\
\% \text { within the source } \\
\% \text { within incidents published } \\
\text { by the channel }\end{array}$ & $\begin{array}{l}0 \\
0.0 \% \\
0.0 \%\end{array}$ & $\begin{array}{l}0 \\
0.0 \% \\
0.0 \%\end{array}$ & $\begin{array}{l}3 \\
75.0 \% \\
2.6 \%\end{array}$ & $\begin{array}{l}3(17) \\
100.0 \% \\
1.8 \%\end{array}$ \\
\hline Other sources & $\begin{array}{l}\text { Count } \\
\% \text { within the source } \\
\% \text { within incidents published } \\
\text { by the channel }\end{array}$ & $\begin{array}{l}0 \\
0.0 \% \\
0.0 \%\end{array}$ & $\begin{array}{l}0 \\
0.0 \% \\
0.0 \%\end{array}$ & $\begin{array}{l}6 \\
100.0 \% \\
5.3 \%\end{array}$ & $\begin{array}{l}6(9) \\
100.0 \% \\
3.6 \%\end{array}$ \\
\hline Total & $\begin{array}{l}\text { Count } \\
\% \text { within the source } \\
\% \text { within incidents published } \\
\text { by the channel }\end{array}$ & $\begin{array}{l}24 \\
14.5 \% \\
100.0 \%\end{array}$ & $\begin{array}{l}27 \\
16.4 \% \\
100.0 \%\end{array}$ & $\begin{array}{l}114 \\
69.1 \% \\
100.0 \%\end{array}$ & $\begin{array}{l}165(233) \\
100.0 \% \\
100.0 \%\end{array}$ \\
\hline
\end{tabular}


Table 4. Types of incidents on different dairy product types vs. reporting channels

\begin{tabular}{|c|c|c|c|c|c|}
\hline $\begin{array}{l}\text { Product } \\
\text { type }\end{array}$ & & $\begin{array}{l}\text { Both } \\
\text { government } \\
\text { and media }\end{array}$ & $\begin{array}{l}\text { Government } \\
\text { only }\end{array}$ & Media only & $\begin{array}{l}\text { Total } \\
\text { incidents } \\
\text { (Total } \\
\text { reports) }\end{array}$ \\
\hline $\begin{array}{l}\text { Milk } \\
\text { powder }\end{array}$ & $\begin{array}{l}\text { Count } \\
\% \text { within the type } \\
\% \text { within incidents published } \\
\text { by the channel }\end{array}$ & $\begin{array}{l}11 \\
15.3 \% \\
45.8 \%\end{array}$ & $\begin{array}{l}14 \\
18.1 \% \\
51.9 \%\end{array}$ & $\begin{array}{l}47 \\
66.7 \% \\
41.2 \%\end{array}$ & $\begin{array}{l}72(99) \\
100.0 \% \\
43.6 \%\end{array}$ \\
\hline Fresh milk & $\begin{array}{l}\text { Count } \\
\% \text { within the type } \\
\% \text { within incidents published } \\
\text { by the channel }\end{array}$ & $\begin{array}{l}2 \\
3.5 \% \\
8.3 \%\end{array}$ & $\begin{array}{l}5 \\
8.8 \% \\
18.5 \%\end{array}$ & $\begin{array}{l}50 \\
87.7 \% \\
43.9 \%\end{array}$ & $\begin{array}{l}57(93) \\
100.0 \% \\
34.5 \%\end{array}$ \\
\hline $\begin{array}{l}\text { Milk } \\
\text { beverage }\end{array}$ & $\begin{array}{l}\text { Count } \\
\% \text { within the type } \\
\% \text { within incidents published } \\
\text { by the channel }\end{array}$ & $\begin{array}{l}3 \\
25.0 \% \\
12.5 \%\end{array}$ & $\begin{array}{l}3 \\
25.0 \% \\
11.1 \%\end{array}$ & $\begin{array}{l}6 \\
50.0 \% \\
5.3 \%\end{array}$ & $\begin{array}{l}12(15) \\
100.0 \% \\
7.3 \%\end{array}$ \\
\hline Yogurt & $\begin{array}{l}\text { Count } \\
\% \text { within the type } \\
\% \text { within incidents published } \\
\text { by the channel }\end{array}$ & $\begin{array}{l}4 \\
33.3 \% \\
16.7 \%\end{array}$ & $\begin{array}{l}3 \\
25.0 \% \\
11.1 \%\end{array}$ & $\begin{array}{l}5 \\
41.7 \% \\
4.4 \%\end{array}$ & $\begin{array}{l}12(14) \\
100.0 \% \\
7.3 \%\end{array}$ \\
\hline $\begin{array}{l}\text { Cheese and } \\
\text { cream }\end{array}$ & $\begin{array}{l}\text { Count } \\
\% \text { within the type } \\
\% \text { within incidents published } \\
\text { by the channel }\end{array}$ & $\begin{array}{l}0 \\
0.0 \% \\
0.0 \%\end{array}$ & $\begin{array}{l}1 \\
33.3 \% \\
3.7 \%\end{array}$ & $\begin{array}{l}2 \\
66.7 \% \\
1.8 \%\end{array}$ & $\begin{array}{l}3(3) \\
100.0 \% \\
1.8 \%\end{array}$ \\
\hline $\begin{array}{l}\text { Other dairy } \\
\text { products }\end{array}$ & $\begin{array}{l}\text { Count } \\
\% \text { within the type } \\
\% \text { within incidents published } \\
\text { by the channel }\end{array}$ & $\begin{array}{l}4 \\
44.4 \% \\
16.7 \%\end{array}$ & $\begin{array}{l}1 \\
11.1 \% \\
3.7 \%\end{array}$ & $\begin{array}{l}4 \\
44.4 \% \\
3.5 \%\end{array}$ & $\begin{array}{l}9(9) \\
100.0 \% \\
5.5 \%\end{array}$ \\
\hline Total & $\begin{array}{l}\text { Count } \\
\% \text { within the type } \\
\% \text { within incidents published } \\
\text { by the channel }\end{array}$ & $\begin{array}{l}24 \\
14.5 \% \\
100.0 \%\end{array}$ & $\begin{array}{l}27 \\
16.4 \% \\
100.0 \%\end{array}$ & $\begin{array}{l}114 \\
69.1 \% \\
100.0 \%\end{array}$ & $\begin{array}{l}165(233) \\
100.0 \% \\
100.0 \%\end{array}$ \\
\hline
\end{tabular}


Table 5. The causes of dairy related food safety incidents vs. reporting channels

\begin{tabular}{|c|c|c|c|c|c|}
\hline Cause & & $\begin{array}{l}\text { Both } \\
\text { government } \\
\text { and media }\end{array}$ & $\begin{array}{l}\text { Government } \\
\text { only }\end{array}$ & $\begin{array}{l}\text { Media } \\
\text { only }\end{array}$ & $\begin{array}{l}\text { Total } \\
\text { incidents } \\
\text { (Total } \\
\text { reports) }\end{array}$ \\
\hline $\begin{array}{l}\text { Microbial } \\
\text { contamination }\end{array}$ & $\begin{array}{l}\text { Count } \\
\% \text { within the cause } \\
\% \text { within incidents published } \\
\text { by the channel }\end{array}$ & $\begin{array}{l}3 \\
9.7 \% \\
12.5 \%\end{array}$ & $\begin{array}{l}10 \\
32.3 \% \\
37.0 \%\end{array}$ & $\begin{array}{l}18 \\
58.1 \% \\
15.8 \%\end{array}$ & $\begin{array}{l}31(39) \\
100.0 \% \\
18.8 \%\end{array}$ \\
\hline $\begin{array}{l}\text { Substandard } \\
\text { nutrition }\end{array}$ & $\begin{array}{l}\text { Count } \\
\% \text { within the cause } \\
\% \text { within incidents published } \\
\text { by the channel }\end{array}$ & $\begin{array}{l}4 \\
16.0 \% \\
16.7 \%\end{array}$ & $\begin{array}{l}3 \\
12.0 \% \\
11.1 \%\end{array}$ & $\begin{array}{l}18 \\
72.0 \% \\
15.8 \%\end{array}$ & $\begin{array}{l}25(38) \\
100.0 \% \\
15.2 \%\end{array}$ \\
\hline $\begin{array}{l}\text { Counterfeit } \\
\text { products }\end{array}$ & $\begin{array}{l}\text { Count } \\
\% \text { within the cause } \\
\% \text { within incidents published } \\
\text { by the channel }\end{array}$ & $\begin{array}{l}4 \\
17.4 \% \\
16.7 \%\end{array}$ & $\begin{array}{l}1 \\
4.3 \% \\
3.7 \%\end{array}$ & $\begin{array}{l}18 \\
78.3 \% \\
15.8 \%\end{array}$ & $\begin{array}{l}23(33) \\
100.0 \% \\
13.9 \%\end{array}$ \\
\hline $\begin{array}{l}\text { Product } \\
\text { adulteration }\end{array}$ & $\begin{array}{l}\text { Count } \\
\% \text { within the cause } \\
\% \text { within incidents published } \\
\text { by the channel }\end{array}$ & $\begin{array}{l}5 \\
25.0 \% \\
20.8 \%\end{array}$ & $\begin{array}{l}5 \\
25.0 \% \\
18.5 \%\end{array}$ & $\begin{array}{l}10 \\
50.0 \% \\
8.8 \%\end{array}$ & $\begin{array}{l}20(47) \\
100.0 \% \\
12.1 \%\end{array}$ \\
\hline $\begin{array}{l}\text { Out of date/ } \\
\text { expired products }\end{array}$ & $\begin{array}{l}\text { Count } \\
\% \text { within the cause } \\
\% \text { within incidents published } \\
\text { by the channel }\end{array}$ & $\begin{array}{l}2 \\
16.7 \% \\
8.3 \%\end{array}$ & $\begin{array}{l}0 \\
0.0 \% \\
0.0 \%\end{array}$ & $\begin{array}{l}10 \\
83.3 \% \\
8.8 \%\end{array}$ & $\begin{array}{l}12(13) \\
100.0 \% \\
7.3 \%\end{array}$ \\
\hline $\begin{array}{l}\text { Foreign body } \\
\text { contamination }\end{array}$ & $\begin{array}{l}\text { Count } \\
\% \text { within the cause } \\
\% \text { within incidents published } \\
\text { by the channel }\end{array}$ & $\begin{array}{l}0 \\
0.0 \% \\
0.0 \%\end{array}$ & $\begin{array}{l}0 \\
0.0 \% \\
0.0 \%\end{array}$ & $\begin{array}{l}10 \\
100.0 \% \\
8.8 \%\end{array}$ & $\begin{array}{l}10(11) \\
100.0 \% \\
6.1 \%\end{array}$ \\
\hline $\begin{array}{l}\text { Insect } \\
\text { contamination }\end{array}$ & $\begin{array}{l}\text { Count } \\
\% \text { within the cause } \\
\% \text { within incidents published } \\
\text { by the channel }\end{array}$ & $\begin{array}{l}0 \\
0.0 \% \\
0.0 \%\end{array}$ & $\begin{array}{l}0 \\
0.0 \% \\
0.0 \%\end{array}$ & $\begin{array}{l}10 \\
100.0 \% \\
8.8 \%\end{array}$ & $\begin{array}{l}10(11) \\
100.0 \% \\
6.1 \%\end{array}$ \\
\hline Food additives & $\begin{array}{l}\text { Count } \\
\% \text { within the cause } \\
\% \text { within incidents published } \\
\text { by the channel }\end{array}$ & $\begin{array}{l}2 \\
22.2 \% \\
8.3 \%\end{array}$ & $\begin{array}{l}3 \\
33.3 \% \\
11.1 \%\end{array}$ & $\begin{array}{l}4 \\
44.4 \% \\
3.5 \%\end{array}$ & $\begin{array}{l}9(10) \\
100.0 \% \\
5.5 \%\end{array}$ \\
\hline Reprocessed & Count & 1 & 1 & 2 & $4(8)$ \\
\hline
\end{tabular}




\begin{tabular}{l|l|llll} 
products & $\begin{array}{l}\text { \% within the cause } \\
\text { \% within incidents published } \\
\text { by the channel }\end{array}$ & $\begin{array}{l}25.0 \% \\
4.2 \%\end{array}$ & $\begin{array}{l}25.0 \% \\
3.7 \%\end{array}$ & $\begin{array}{l}50.0 \% \\
1.8 \%\end{array}$ & $\begin{array}{l}100.0 \% \\
2.4 \%\end{array}$ \\
\hline Others & $\begin{array}{l}\text { Count } \\
\text { \% within the cause } \\
\text { \% within incidents published } \\
\text { by the channel }\end{array}$ & $12.5 \%$ & $14.8 \%$ & $12.3 \%$ & $12.7 \%$ \\
\hline Total & $\begin{array}{l}\text { Count } \\
\text { \% within the cause }\end{array}$ & $14.5 \%$ & $16.4 \%$ & $69.1 \%$ & $100.0 \%$ \\
\hline 36 & $\begin{array}{l}\text { \% within incidents published } \\
\text { by the channel }\end{array}$ & $100.0 \%$ & $100.0 \%$ & $100.0 \%$ & $100.0 \%$ \\
\hline
\end{tabular}

737 Note: in this work product adulteration is considered to be the intentional addition or substitution of a material 738 within a food product for the perpetrators to derive economic benefit from doing so. Counterfeit products are 739 considered to be those products that are made to look like or be an exact replica or imitation of another product 740 with the motive of deceiving or defrauding to provide an economic benefit for the perpetrators. 
Table 6. The provinces of dairy related food safety incidents vs. reporting channels

\begin{tabular}{|c|c|c|c|c|c|}
\hline Province & & $\begin{array}{l}\text { Both } \\
\text { government } \\
\text { and media }\end{array}$ & $\begin{array}{l}\text { Government } \\
\text { only }\end{array}$ & Media only & $\begin{array}{l}\text { Total } \\
\text { incidents } \\
\text { (Total } \\
\text { reports) }\end{array}$ \\
\hline $\begin{array}{l}\text { Multiple } \\
\text { provinces }\end{array}$ & $\begin{array}{l}\text { Count } \\
\% \text { within the area } \\
\% \text { within incidents published } \\
\text { by the channel }\end{array}$ & $\begin{array}{l}7 \\
17.1 \% \\
29.2 \%\end{array}$ & $\begin{array}{l}8 \\
19.5 \% \\
29.6 \%\end{array}$ & $\begin{array}{l}26 \\
63.4 \% \\
22.8 \%\end{array}$ & $\begin{array}{l}41(63) \\
100.0 \% \\
24.8 \%\end{array}$ \\
\hline Guangdong & $\begin{array}{l}\text { Count } \\
\% \text { within the area } \\
\% \text { within incidents published } \\
\text { by the channel }\end{array}$ & $\begin{array}{l}3 \\
14.3 \% \\
12.5 \%\end{array}$ & $\begin{array}{l}5 \\
23.8 \% \\
18.5 \%\end{array}$ & $\begin{array}{l}13 \\
61.9 \% \\
11.4 \%\end{array}$ & $\begin{array}{l}21(27) \\
100.0 \% \\
12.7 \%\end{array}$ \\
\hline Shanghai & $\begin{array}{l}\text { Count } \\
\% \text { within the area } \\
\% \text { within incidents published } \\
\text { by the channel }\end{array}$ & $\begin{array}{l}3 \\
18.8 \% \\
12.5 \%\end{array}$ & $\begin{array}{l}2 \\
12.5 \% \\
7.4 \%\end{array}$ & $\begin{array}{l}11 \\
68.8 \% \\
9.6 \%\end{array}$ & $\begin{array}{l}16(21) \\
100.0 \% \\
9.7 \%\end{array}$ \\
\hline Beijing & $\begin{array}{l}\text { Count } \\
\% \text { within the area } \\
\% \text { within incidents published } \\
\text { by the channel }\end{array}$ & $\begin{array}{l}0 \\
0.0 \% \\
0.0 \%\end{array}$ & $\begin{array}{l}4 \\
25.0 \% \\
14.8 \%\end{array}$ & $\begin{array}{l}12 \\
75.0 \% \\
10.5 \%\end{array}$ & $\begin{array}{l}16(20) \\
100.0 \% \\
9.7 \%\end{array}$ \\
\hline Zhejiang & $\begin{array}{l}\text { Count } \\
\% \text { within the area } \\
\% \text { within incidents published } \\
\text { by the channel }\end{array}$ & $\begin{array}{l}1 \\
9.1 \% \\
4.2 \%\end{array}$ & $\begin{array}{l}0 \\
0.0 \% \\
0.0 \%\end{array}$ & $\begin{array}{l}10 \\
90.9 \% \\
8.8 \%\end{array}$ & $\begin{array}{l}11(22) \\
100.0 \% \\
6.7 \%\end{array}$ \\
\hline Shandong & $\begin{array}{l}\text { Count } \\
\% \text { within the area } \\
\% \text { within incidents published } \\
\text { by the channel }\end{array}$ & $\begin{array}{l}1 \\
14.3 \% \\
4.2 \%\end{array}$ & $\begin{array}{l}0 \\
0.0 \% \\
0.0 \%\end{array}$ & $\begin{array}{l}6 \\
85.7 \% \\
5.3 \%\end{array}$ & $\begin{array}{l}7(7) \\
100.0 \% \\
4.2 \%\end{array}$ \\
\hline Hebei & $\begin{array}{l}\text { Count } \\
\% \text { within the area } \\
\% \text { within incidents published } \\
\text { by the channel }\end{array}$ & $\begin{array}{l}1 \\
20.0 \% \\
4.2 \%\end{array}$ & $\begin{array}{l}1 \\
20.0 \% \\
3.7 \%\end{array}$ & $\begin{array}{l}3 \\
60.0 \% \\
2.6 \%\end{array}$ & $\begin{array}{l}5(9) \\
100.0 \% \\
3.0 \%\end{array}$ \\
\hline Jiangsu & $\begin{array}{l}\text { Count } \\
\% \text { within the area } \\
\% \text { within incidents published } \\
\text { by the channel }\end{array}$ & $\begin{array}{l}1 \\
20.0 \% \\
4.2 \%\end{array}$ & $\begin{array}{l}0 \\
0.0 \% \\
0.0 \%\end{array}$ & $\begin{array}{l}4 \\
80.0 \% \\
3.5 \%\end{array}$ & $\begin{array}{l}5(6) \\
100.0 \% \\
3.0 \%\end{array}$ \\
\hline Hunan & Count & 1 & 0 & 3 & $4(6)$ \\
\hline
\end{tabular}




\begin{tabular}{|c|c|c|c|c|c|}
\hline & $\begin{array}{l}\% \text { within the area } \\
\% \text { within incidents published } \\
\text { by the channel }\end{array}$ & $\begin{array}{l}25.0 \% \\
4.2 \%\end{array}$ & $\begin{array}{l}0.0 \% \\
0.0 \%\end{array}$ & $\begin{array}{l}75.0 \% \\
2.6 \%\end{array}$ & $\begin{array}{l}100.0 \% \\
2.4 \%\end{array}$ \\
\hline Guangxi & $\begin{array}{l}\text { Count } \\
\% \text { within the area } \\
\% \text { within incidents published } \\
\text { by the channel }\end{array}$ & $\begin{array}{l}0 \\
0.0 \% \\
0.0 \%\end{array}$ & $\begin{array}{l}0 \\
0.0 \% \\
0.0 \%\end{array}$ & $\begin{array}{l}1 \\
100.0 \% \\
0.9 \%\end{array}$ & $\begin{array}{l}1(10) \\
100.0 \% \\
0.6 \%\end{array}$ \\
\hline $\begin{array}{l}\text { Other } \\
\text { provinces }\end{array}$ & $\begin{array}{l}\text { Count } \\
\% \text { within the area } \\
\% \text { within incidents published } \\
\text { by the channel }\end{array}$ & $\begin{array}{l}6 \\
15.8 \% \\
25.0 \%\end{array}$ & $\begin{array}{l}7 \\
18.4 \% \\
25.9 \%\end{array}$ & $\begin{array}{l}25 \\
65.8 \% \\
21.9 \%\end{array}$ & $\begin{array}{l}38(42) \\
100.0 \% \\
23.0 \%\end{array}$ \\
\hline Total & $\begin{array}{l}\text { Count } \\
\% \text { within the area } \\
\% \text { within incidents published } \\
\text { by the channel }\end{array}$ & $\begin{array}{l}24 \\
14.5 \% \\
100.0 \%\end{array}$ & $\begin{array}{l}27 \\
16.4 \% \\
100.0 \%\end{array}$ & $\begin{array}{l}114 \\
69.1 \% \\
100.0 \%\end{array}$ & $\begin{array}{l}165(233) \\
100.0 \% \\
100.0 \%\end{array}$ \\
\hline
\end{tabular}


Table 7. The location of dairy related food safety incidents vs types of channels

\begin{tabular}{|c|c|c|c|c|c|}
\hline Location & & $\begin{array}{l}\text { Both } \\
\text { government } \\
\text { and media }\end{array}$ & $\begin{array}{l}\text { Government } \\
\text { only }\end{array}$ & Media only & $\begin{array}{l}\text { Total } \\
\text { incidents } \\
\text { (Total } \\
\text { reports) }\end{array}$ \\
\hline Not specified & $\begin{array}{l}\text { Count } \\
\% \text { within the location } \\
\% \text { within incidents published } \\
\text { by the channel }\end{array}$ & $\begin{array}{l}22 \\
22.9 \% \\
91.7 \%\end{array}$ & $\begin{array}{l}26 \\
27.1 \% \\
96.3 \%\end{array}$ & $\begin{array}{l}48 \\
50.0 \% \\
42.1 \%\end{array}$ & $\begin{array}{l}96(136) \\
100.0 \% \\
58.2 \%\end{array}$ \\
\hline Home & $\begin{array}{l}\text { Count } \\
\% \text { within the location } \\
\% \text { within incidents published } \\
\text { by the channel }\end{array}$ & $\begin{array}{l}2 \\
4.1 \% \\
8.3 \%\end{array}$ & $\begin{array}{l}1 \\
2.0 \% \\
3.7 \%\end{array}$ & $\begin{array}{l}46 \\
93.9 \% \\
40.4 \%\end{array}$ & $\begin{array}{l}49(53) \\
100.0 \% \\
29.7 \%\end{array}$ \\
\hline Factories & $\begin{array}{l}\text { Count } \\
\% \text { within the location } \\
\% \text { within incidents published } \\
\text { by the channel }\end{array}$ & $\begin{array}{l}0 \\
0.0 \% \\
0.0 \%\end{array}$ & $\begin{array}{l}0 \\
0.0 \% \\
0.0 \%\end{array}$ & $\begin{array}{l}7 \\
100.0 \% \\
6.1 \%\end{array}$ & $\begin{array}{l}7(15) \\
100.0 \% \\
4.2 \%\end{array}$ \\
\hline Farms & $\begin{array}{l}\text { Count } \\
\% \text { within the location } \\
\% \text { within incidents published } \\
\text { by the channel }\end{array}$ & $\begin{array}{l}0 \\
0.0 \% \\
0.0 \%\end{array}$ & $\begin{array}{l}0 \\
0.0 \% \\
0.0 \%\end{array}$ & $\begin{array}{l}2 \\
100.0 \% \\
1.8 \%\end{array}$ & $\begin{array}{l}2(14) \\
100.0 \% \\
1.2 \%\end{array}$ \\
\hline Retailers & $\begin{array}{l}\text { Count } \\
\% \text { within the location } \\
\% \text { within incidents published } \\
\text { by the channel }\end{array}$ & $\begin{array}{l}0 \\
0.0 \% \\
0.0 \%\end{array}$ & $\begin{array}{l}0 \\
0.0 \% \\
0.0 \%\end{array}$ & $\begin{array}{l}8 \\
100.0 \% \\
7.0 \%\end{array}$ & $\begin{array}{l}8(11) \\
100.0 \% \\
4.8 \%\end{array}$ \\
\hline Schools & $\begin{array}{l}\text { Count } \\
\% \text { within the location } \\
\% \text { within incidents published } \\
\text { by the channel }\end{array}$ & $\begin{array}{l}0 \\
0.0 \% \\
0.0 \%\end{array}$ & $\begin{array}{l}0 \\
0.0 \% \\
0.0 \%\end{array}$ & $\begin{array}{l}3 \\
100.0 \% \\
2.6 \%\end{array}$ & $\begin{array}{l}3(4) \\
100.0 \% \\
1.8 \%\end{array}$ \\
\hline Total & $\begin{array}{l}\text { Count } \\
\% \text { within the location } \\
\% \text { within incidents published } \\
\text { by the channel }\end{array}$ & $\begin{array}{l}24 \\
14.5 \% \\
100.0 \%\end{array}$ & $\begin{array}{l}27 \\
16.4 \% \\
100.0 \%\end{array}$ & $\begin{array}{l}114 \\
69.1 \% \\
100.0 \%\end{array}$ & $\begin{array}{l}165(233) \\
100.0 \% \\
100.0 \%\end{array}$ \\
\hline
\end{tabular}


Table 8. Other areas included in reporting of dairy related food safety incidents.

\begin{tabular}{l|cc|cc}
\hline \multirow{2}{*}{ Other areas included } & \multicolumn{2}{|c|}{ Government reports } & \multicolumn{2}{c}{ Media reports } \\
\cline { 2 - 4 } & Number & Proportion & Number & Proportion \\
\hline Reaction of the government & 45 & $81.8 \%$ & 35 & $19.7 \%$ \\
Knowledge about the incidents & 8 & $14.5 \%$ & 59 & $33.1 \%$ \\
Linking with previous incidents & 0 & $0.0 \%$ & 36 & $20.2 \%$ \\
Reaction of dairy companies & 2 & $3.6 \%$ & 29 & $16.3 \%$ \\
Comments on the government & 0 & $0.0 \%$ & 23 & $8.4 \%$ \\
Suggestions for consumers & 3 & $5.5 \%$ & 15 & $8.4 \%$ \\
Market research & 0 & $0.0 \%$ & 15 & $2.2 \%$ \\
Others & 0 & $0.0 \%$ & 4 & $8.9 \%$ \\
\hline
\end{tabular}

754 
Table 9. The features of the dairy related incidents reported by both government and media

\begin{tabular}{|c|c|c|c|c|}
\hline \multicolumn{2}{|c|}{ Feature of the incidents } & Government earlier & Media earlier & Total \\
\hline \multirow[t]{7}{*}{ Type } & Milk powder & 10 & 1 & 11 \\
\hline & Fresh milk & 2 & 1 & 3 \\
\hline & Milk beverage & 2 & 1 & 3 \\
\hline & Yogurt & 3 & 0 & 3 \\
\hline & Cheese and cream & 0 & 0 & 0 \\
\hline & Other dairy products & 4 & 0 & 4 \\
\hline & Total & 21 & 3 & 24 \\
\hline \multirow[t]{11}{*}{ Cause } & Non-food raw material & 3 & 2 & 5 \\
\hline & Microbial contamination & 3 & 0 & 3 \\
\hline & Substandard nutrition & 4 & 0 & 4 \\
\hline & Counterfeit products & 3 & 1 & 4 \\
\hline & Out of date/expired products & 2 & 0 & 2 \\
\hline & Foreign bodies & 0 & 0 & 0 \\
\hline & Insect contamination & 0 & 0 & 0 \\
\hline & Food additives & 2 & 0 & 2 \\
\hline & Reprocessed products & 1 & 0 & 1 \\
\hline & Others & 3 & 0 & 3 \\
\hline & Total & 21 & 3 & 24 \\
\hline \multirow[t]{12}{*}{ Province } & Multiple provinces & 4 & 3 & 7 \\
\hline & Guangdong & 3 & 0 & 3 \\
\hline & Zhejiang & 1 & 0 & 1 \\
\hline & Shanghai & 3 & 0 & 3 \\
\hline & Beijing & 0 & 0 & 0 \\
\hline & Guangxi & 0 & 0 & 0 \\
\hline & Hebei & 1 & 0 & 1 \\
\hline & Shandong & 1 & 0 & 1 \\
\hline & Hunan & 1 & 0 & 1 \\
\hline & Jiangsu & 1 & 0 & 1 \\
\hline & Others & 6 & 0 & 6 \\
\hline & Total & 21 & 3 & 24 \\
\hline Location & Not specified & 19 & 2 & 21 \\
\hline
\end{tabular}




\begin{tabular}{l|c|ccc} 
Home & 1 & 0 & 1 \\
Factories & 1 & 1 & 2 \\
Farms & 0 & 0 & 0 \\
Retailers & 0 & 0 & 0 \\
Schools & Total & 0 & 0 & 0 \\
& 21 & 3 & 24 \\
\hline
\end{tabular}

759

760

761

762

763 
Figure 1. Pyramid of laws and regulations in China (Adapted from Jia \& Jukes, 2013 p.

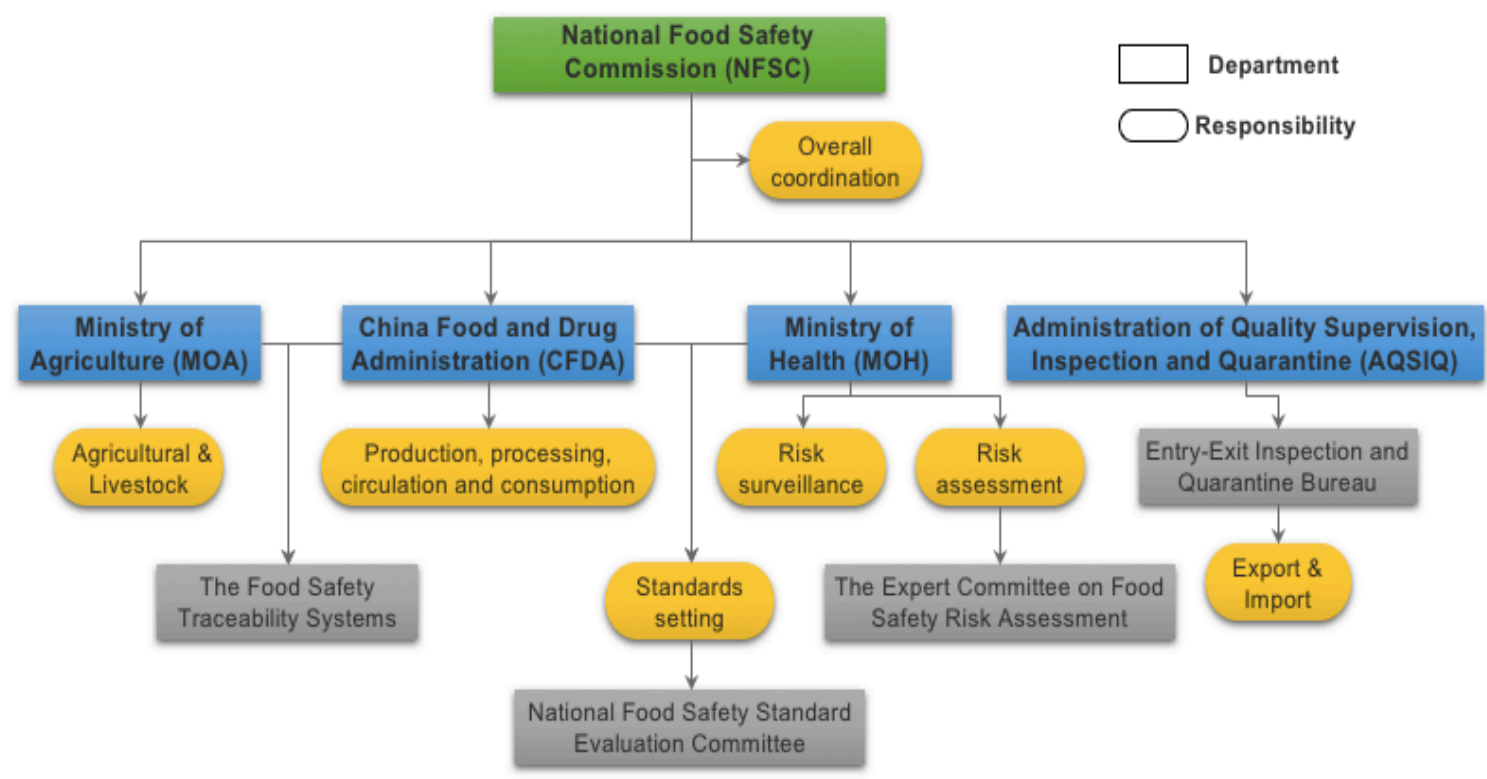

Figure 2. The current government authorities involved in food safety supervision and 
China Food and Drug

Administration (CFDA)

Ministry of Health (MoH)
-Food risk exposure

- Food crisis emergency

-Food recall

- National food safety standards and overall coodination for food safety management

- Food risk alerts and major food safety incidents

Ministry of Agriculture (MoA)
-Edible agricltural products food safety information exposure

Administration of Quality

Supervision, Inspection

and Quarantine (AQSIQ)

- Food safety information on food production, food related products, imported and exported food products

$$
\begin{aligned}
& \text { 三元纯牛奶 } \\
& \text { 二氧化氯保鲜生奶 } \\
& \text { 婴儿1段奶粉 } \\
& \text { 奶茶婴儿奶粉奶粉造假 } \\
& \text { 喜康宝奶粉营养酸奶、然伊利奶粉 } \\
& \text { 不合格奶粉惠氏启赋奶粉 } \\
& \text { 奶企留 婴幼儿奶粉 造牛奶 } \\
& \text { 南山婴儿奶粉紫牛奶掺牛尿三聚腈胺 } \\
& \text { 奶酒牛奶中非法添加二氧化氯奶农 }
\end{aligned}
$$

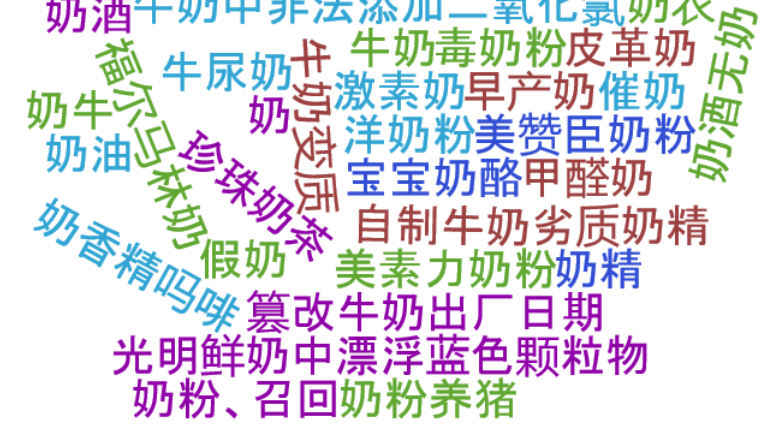




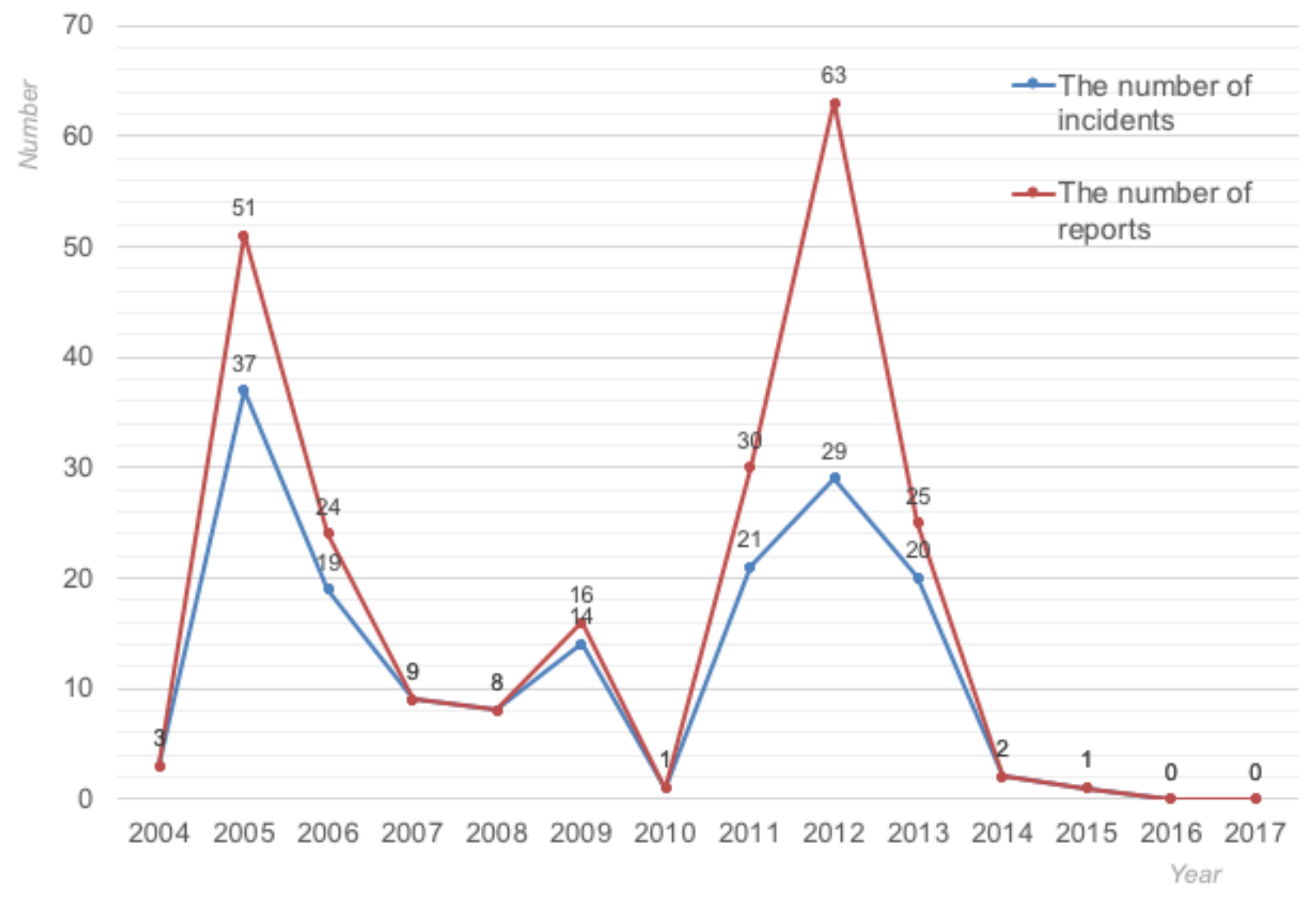

Figure 5. The total number of incidents and reports exposed by government and media 790 between 2004 and 2017

791

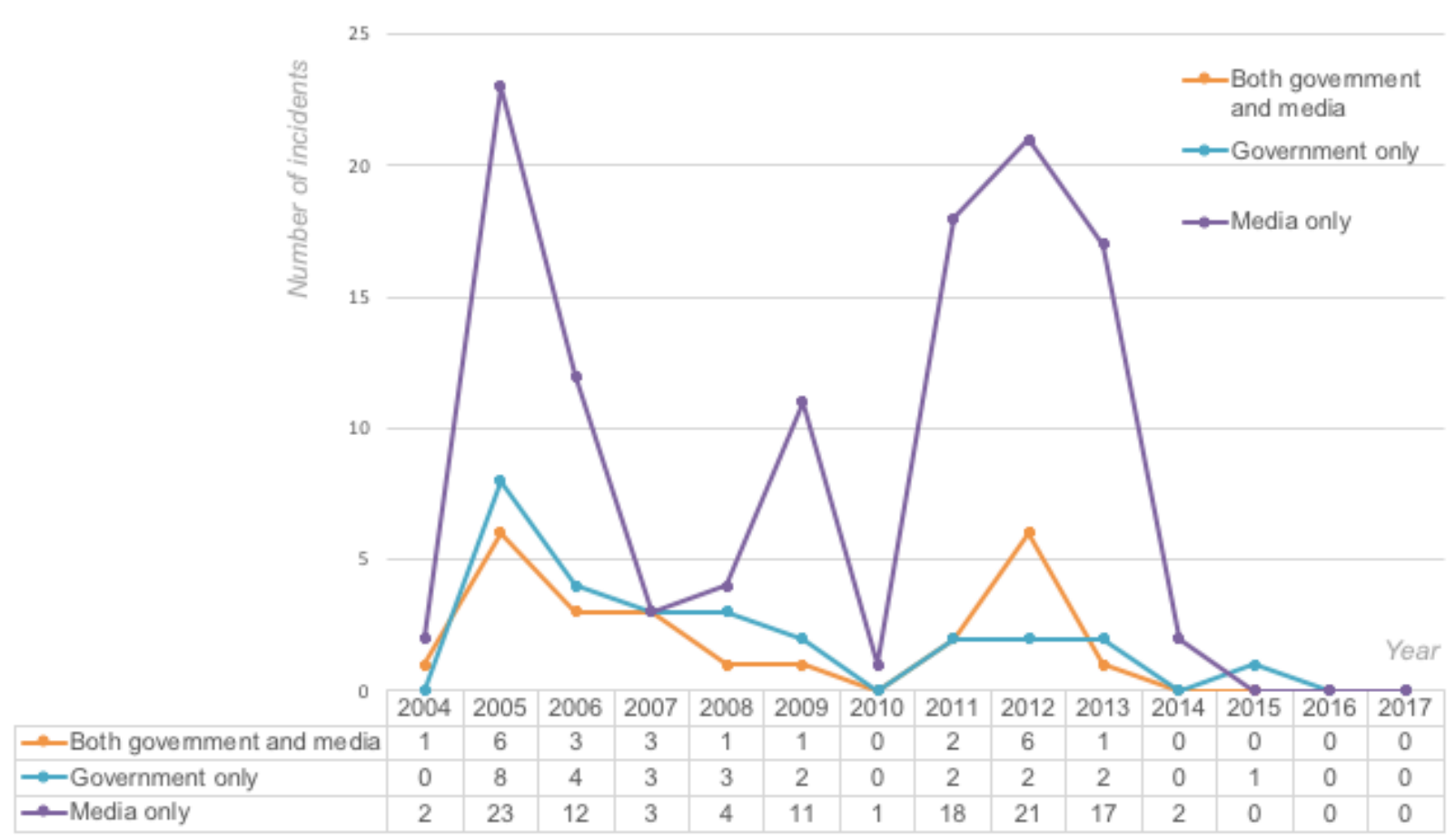

Figure 6. The number of dairy related food safety incidents by government and media 


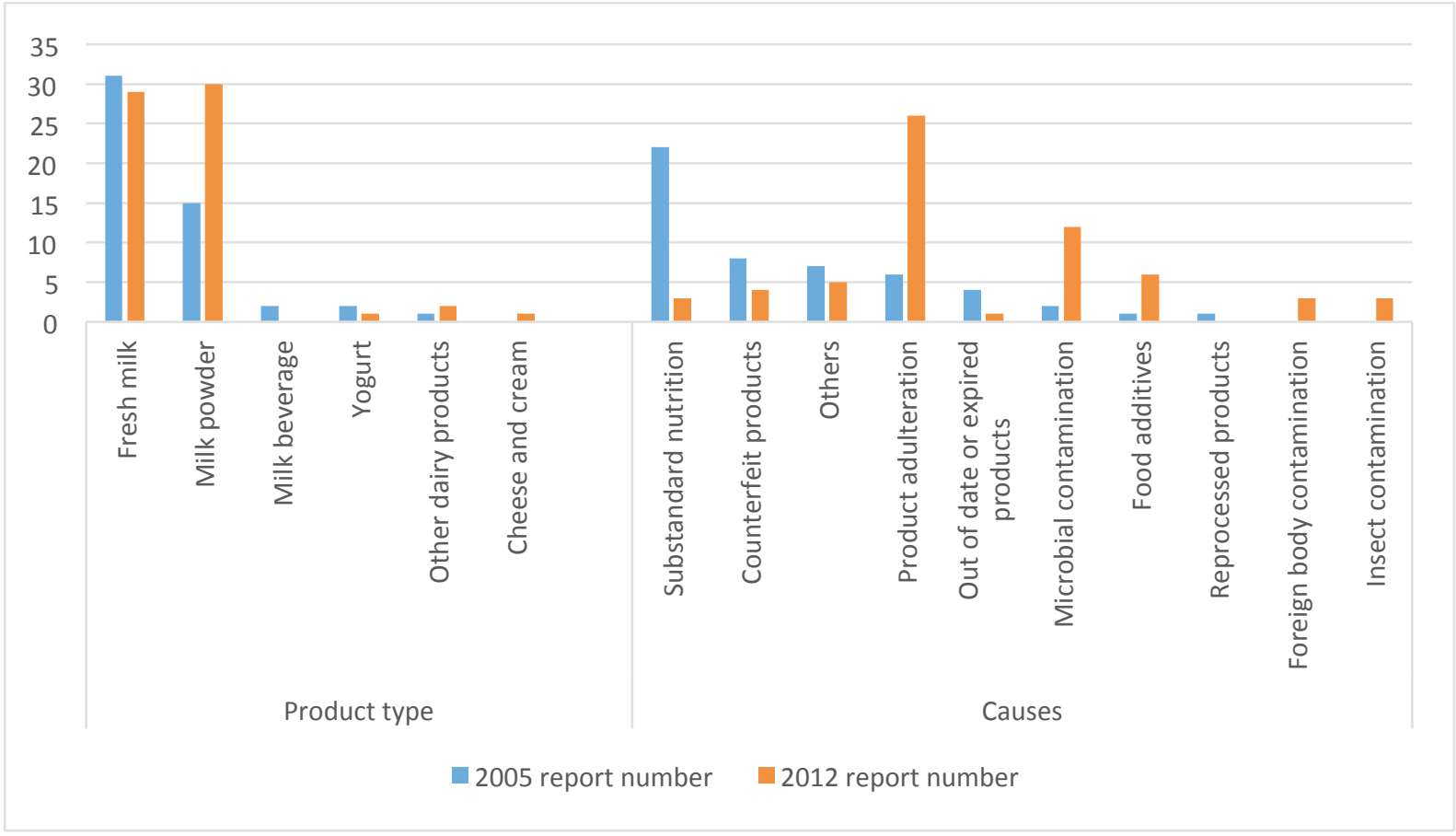

Figure 7. Features of dairy food incidents and reports in 2005 and 2012

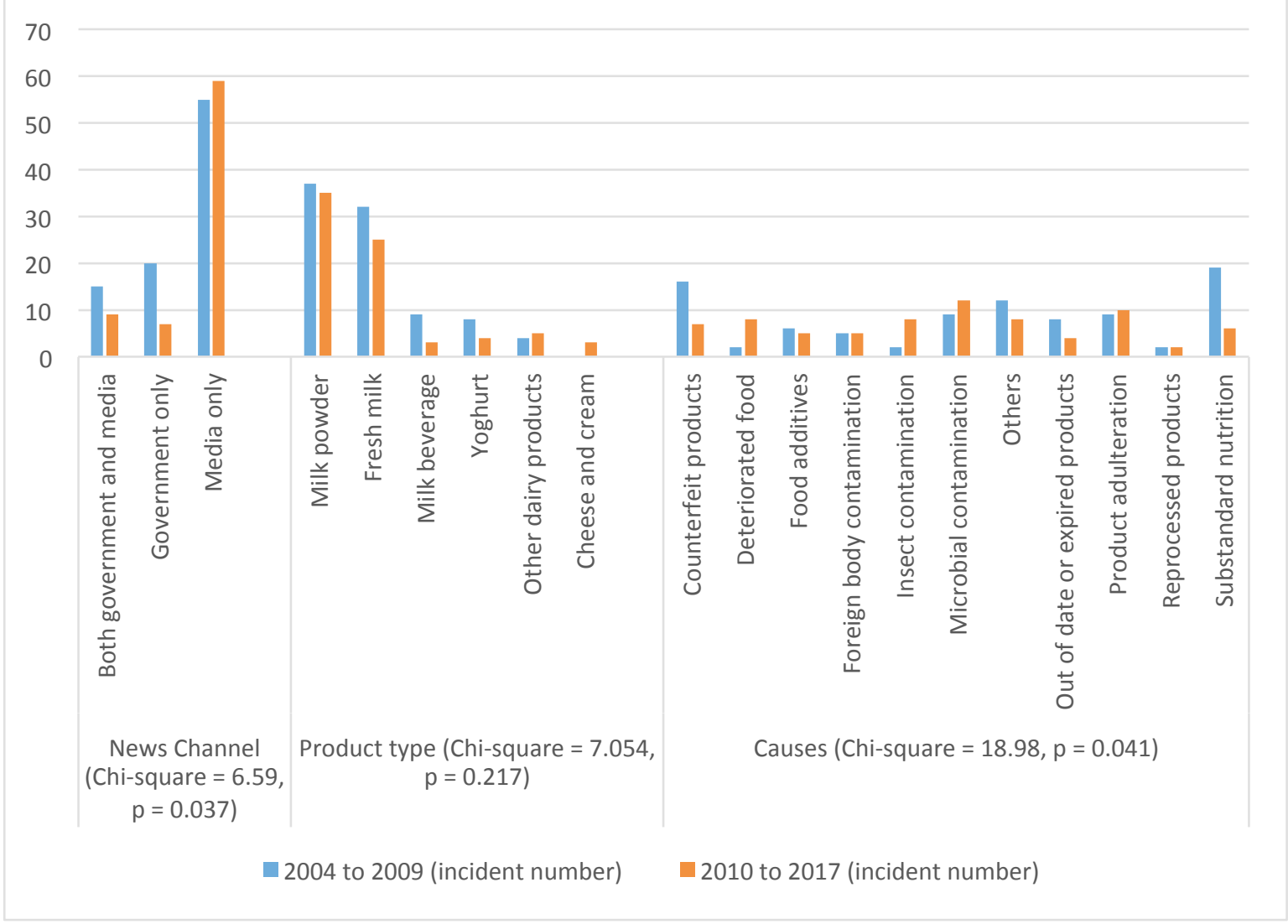

Figure 8. Comparison of features of dairy food incidents in 2004-2009 and 2010-2017 


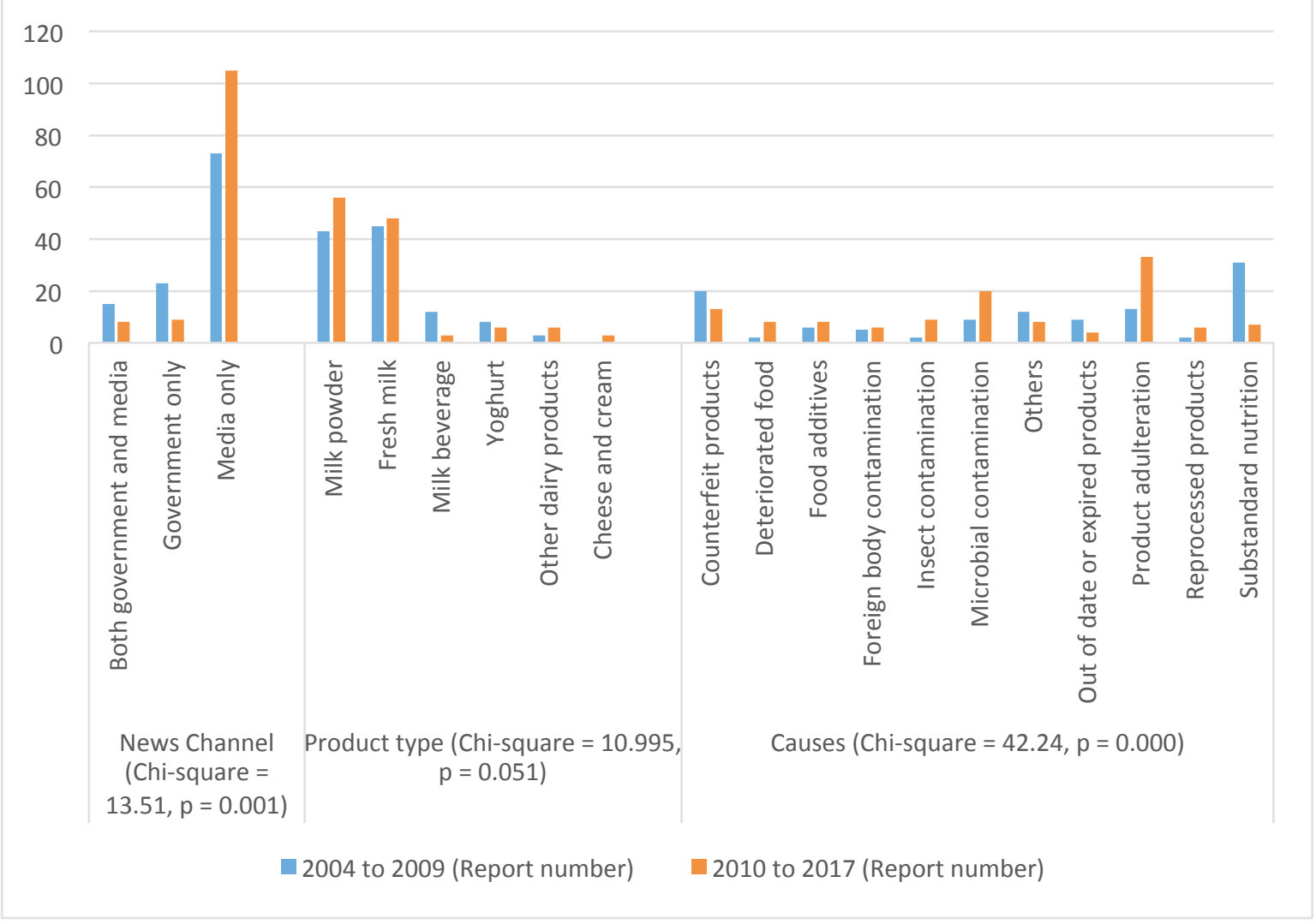

Figure 9. Comparison of features of dairy food safety reporting in 2004-2009 and 2010-2017 
三元纯牛奶 Sanyuan pure milk

不合格奶粉 unqualified milk powder

二氧化氯保鲜生奶 chlorine dioxide

fresh milk

人造牛奶 artificial milk

伊利奶粉 Yili milk powder

假奶 fake milk

催奶 lactation

光明鲜奶中漂浮蓝色颗粒物

floating blue particles in Guangming milk

劣质奶精 inferior creamer

南山婴儿奶粉 Nanshan baby

formula

喜康宝奶粉 Xikangbao milk powder

奶 milk

奶企 dairy enterprise

奶农 dairy farmer

奶油 cream

奶牛 cow

奶粉 milk powder

奶粉、召回 milk powder recall

奶粉养猪 milk powder pig feed

奶粉造假 milk powder fraud

奶精 creamer

奶茶 milk tea

奶酒 cream wine

奶酒无奶 cream wine no cream

奶香精吗啡 cream morphine

贞儿 1 段奶粉 baby formula 1
婴儿奶粉 baby formula

贞幼儿奶粉 baby formula all stages

宝宝奶酪 baby cheese

惠氏启赋奶粉 Wyeth illuma milk powder

早产奶 milk power for

毒奶粉 toxic milk powder

洋奶粉 imported milk powder

激素奶 milk with hormone

牛奶 milk

牛奶中非法添加二氧化氯 illegal addition of chlorine dioxide to milk

牛奶变质 milk deterioration

牛奶掺牛尿 milk mixed with cow urine

牛尿奶 cow urine milk

珍珠奶茶 pearl milk tea

甲醛奶 formaldehyde milk

皮革奶 leather milk

福尔马林奶 formalin in milk

篡改牛奶出厂日期 tampering with date of milk production

纯牛奶 pure milk

美素力奶粉 Frisolac milk powder

美赞臣奶粉 Mead Johnson milk powder

自制牛奶 homemade milk

三聚氰胺 melamine

营养酸奶 nutritious yogurt

酸奶 yogurt 